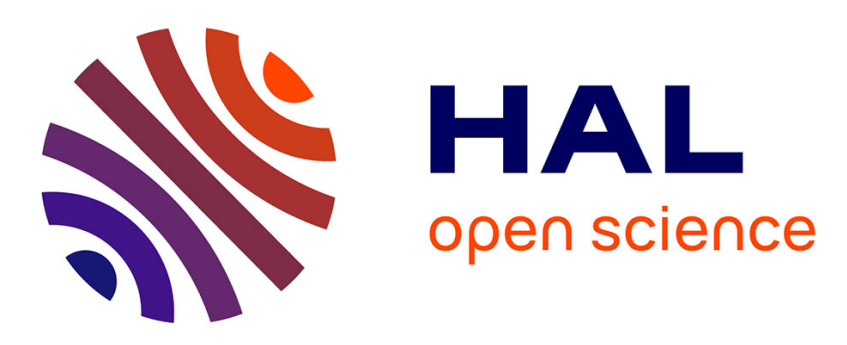

\title{
Bioremediation of PAH-contaminated soils: Consequences on formation and degradation of polar-polycyclic aromatic compounds and microbial community abundance
}

Coralie Biache, Salma Ouali, Aurélie Cébron, Catherine Lorgeoux, Stéfan Colombano, Pierre Faure

\section{To cite this version:}

Coralie Biache, Salma Ouali, Aurélie Cébron, Catherine Lorgeoux, Stéfan Colombano, et al.. Bioremediation of PAH-contaminated soils: Consequences on formation and degradation of polar-polycyclic aromatic compounds and microbial community abundance. Journal of Hazardous Materials, 2017, 329, pp.1 - 10. 10.1016/j.jhazmat.2017.01.026 . hal-01698413

\section{HAL Id: hal-01698413 \\ https://hal.univ-lorraine.fr/hal-01698413}

Submitted on 1 Feb 2018

HAL is a multi-disciplinary open access archive for the deposit and dissemination of scientific research documents, whether they are published or not. The documents may come from teaching and research institutions in France or abroad, or from public or private research centers.
L'archive ouverte pluridisciplinaire HAL, est destinée au dépôt et à la diffusion de documents scientifiques de niveau recherche, publiés ou non, émanant des établissements d'enseignement et de recherche français ou étrangers, des laboratoires publics ou privés. 


\title{
Bioremediation of PAH-contaminated soils: Consequences on formation and degradation of polar-polycyclic aromatic compounds and microbial community abundance
}

\author{
Coralie Biache $^{a, b, *}$, Salma Ouali ${ }^{a, b}$, Aurélie Cébron ${ }^{a, b}$, Catherine Lorgeoux $^{c}$, Stéfan Colombano ${ }^{d}$, \\ Pierre Faure ${ }^{a, b}$
}

\author{
aUniversité de Lorraine, LIEC, UMR7360, Vandœuvre-lès-Nancy 54506, France \\ ${ }^{b}$ CNRS, LIEC, UMR7360, Vandœuvre-lès-Nancy 54506, France \\ 'Université de Lorraine, CNRS, CREGU, GeoRessources lab, UMR7359, Vandœuvre-lès-Nancy 54506, \\ France \\ dBRGM, 3 avenue Claude Guillemin, BP 36009, Orléans Cedex 2 45060, France \\ *Corresponding author at: LIEC, Faculté des Sciences et Technologies, Boulevard des Aiguillettes, B.P. \\ 70239, Vandœuvre-lès-Nancy Cedex 54506, France. \\ E-mail address: coralie.biache@univ-lorraine.fr (C. Biache).
}

Keywords: Polycyclic aromatic hydrocarbon; Availability; Bioslurry; PAH-degrader; Bacteria; Fungi

\begin{abstract}
A bioslurry batch experiment was carried out over five months on three polycyclic aromatic compound (PAC) contaminated soils to study the PAC (PAH and polar-PAC) behavior during soil incubation and to evaluate the impact of PAC contamination on the abundance of microbial communities and functional PAH-degrading populations. Organic matter characteristics and reactivity, assessed through solvent extractable organic matter and PAC contents, and soil organic matter mineralization were monitored during 5 months. Total bacteria and fungi, and PAH-ring hydroxylating dioxygenase genes were quantified. Results showed that PAHs and polar-PACs were degraded with different degradation dynamics. Differences in degradation rates were observed among the three soils depending on PAH distribution and availability. Overall, low molecular weight compounds were preferentially degraded. Degradation selectivity between isomers and structurally similar compounds was observed which could be used to check the efficiency of bioremediation processes. Bacterial communities were dominant over fungi and were most likely responsible for PAC degradation. Abundance of PAHdegrading bacteria increased during incubations, but their proportion in the bacterial communities tended to decrease. The accumulation of some oxygenated-PACs during the bioslurry experiment underlines the necessity to monitor these compounds during application of remediation treatment on PAH contaminated soils.
\end{abstract}




\section{Introduction}

Among regulatory substances, polycyclic aromatic hydrocarbons (PAHs) represent the most encountered family of organic contaminants, impacting more than 200,000 sites in Europe [1]. Most of them derive from past and present industrial activities involving the production or use of coalderived products (coking plant, gas plant, wood-treating facilities...). The risk assessment of PAH contaminated soils is based on 16 PAHs listed as priority pollutants for their toxic, carcinogenic and mutagenic properties [2]. However, other compounds are encountered in association with these PAHs such as oxygenated- and nitrogenated-polycyclic aromatic compounds (O-PACs and N-PACs). Some of these compounds are also known to exhibit toxic, mutagenic and carcinogenic properties [3-6] and higher water solubility, and consequently mobility, than PAHs [7]. Consequently, they started to gain interest in the past few years and were the subject of several studies $[5,8-13]$ but since they are unregulated, data regarding these compounds remain pretty scarce. They can occur in the initial contamination but can also be formed over time and during remediation treatments $[5,14]$. Detailed studies aimed to determine the degradation pathway of a specific PAH by a specific bacterial or fungal strain and evidenced the implication of O-PACs as intermediates but also dead-end products $[15,16]$ resulting in their potential accumulation in soils after biodegradation treatments and natural attenuation [17-19]. It is then important to get information on their behavior during bioremediation treatments in relation with the dynamic of the soil microbial communities, including those involved in the PAC degradation.

The aims of this study were (i) to investigate the PAC degradation and transformation during soil incubation under conditions favoring microbial activities and (ii) to identify the dynamic of the bacterial and fungal communities and functional populations involved in PAC degradation. To achieve these objectives, bioslurry batch experiment was carried out and monitored on three PAC contaminated soils over 5 months. The selected soils exhibited different status and levels of contamination. 


\section{Experimental}

\subsection{Soil samples}

Three PAC contaminated soils were sampled at a former gas plant site in Rennes (France), at a former coking plant site in Neuves-Maisons (France) and at an active wood-treating facility in Midi-Pyrénées Region (France). After collection, the samples were stored at $-18{ }^{\circ} \mathrm{C}$ before freeze-drying, sieving ( 2 $\mathrm{mm})$ and crushing of the undersize $(<500 \mu \mathrm{m})$. As the freezing and freeze-drying are known to affect the microbiological soil characteristics [20-22], aliquots of "fresh" coking plant and wood-treating facility soils were stored at $4{ }^{\circ} \mathrm{C}$ for the microbial inoculum preparation. Since there was no "fresh" gas plant soil left for the inoculum preparation, the inoculum was obtained from another PAC contaminated soil coming from a site (Toulouse, France) that housed the same activity (i.e. gasification).

\subsection{Bioslurry experiments}

The microbial inocula were prepared from the "fresh" soils (details are given in the Supplementary Data). The three inocula contained high abundance of bacteria (2.106 to $3.10716 \mathrm{~S}$ rDNA copies/ml) while fungi were only found in the gas plant inoculum (2.107 18S rDNA copies/ml) and were not detected in coking plant and wood-treating facility inocula.

Freeze-dried soil samples $(20 \mathrm{~g})$ were placed into $250 \mathrm{~mL}$ Schott bottles, where inoculum $(2 \mathrm{~mL})$ and $\mathrm{BH}$ solution $(18 \mathrm{~mL})$ were added. The bottles were hermetically closed using Teflon coated rubber stopper and caps and placed in an incubation chamber at $28^{\circ} \mathrm{C}$ in the dark under continuous stirring (120 rpm). The soil samples dedicated to initial characterization were stirred for $30 \mathrm{~min}$ to homogenize the slurry before being harvested. In previous experiment (not published) sodium azide was added to similar samples in order to keep the medium sterile for abiotic control but results showed that bacteria were still present. Achten et al. [23] draw the same conclusion from similar experiments as bacteria still occurred in their samples sterilized with sodium azide after two days of bioslurry experiment. Consequently, considering the extensive duration of the experiment (5 months) combined with the 
extreme difficulty to maintain the medium sterile, abiotic controls were not included in this experiment.

Mineralization was monitored during the experiment by measuring the $\mathrm{CO}_{2}$ accumulated into the flask atmosphere three times a week with an infrared Binos analyzer $\left(\lambda 2325.6 \mathrm{~cm}^{-1}\right)$ on $3 \mathrm{~mL}$ of the bottle atmosphere. After each $\mathrm{CO}_{2}$ measurement, the bottles were left open in a hood for 30 min to renew the atmosphere and avoid anaerobic conditions. Once a month the bottles were weighed and the slurry volumes were adjusted with BH solution. After 1.5, 3 and 5 months, triplicate bottles were harvested. All soil samples were stored at $-18^{\circ} \mathrm{C}$ and freeze-dried for organic and microbial analyses.

\subsection{Organic analyses}

\subsubsection{Total organic carbon (TOC) determination}

The TOC content determination was performed on $0.5 \mathrm{~g}$ of dw soil with a total carbon analyzer TOC-V CSH (Shimadzu) associated with a solid sample module SSM-5000A (Shimadzu). The catalytic combustion was performed at $900{ }^{\circ} \mathrm{C}$ after carbonate removal with phosphoric acid ( $\left.10 \% \mathrm{wt}\right)$.

\subsubsection{Organic matter extraction}

Extraction method was adapted from Li et al. [24] and described elsewhere [25]. Briefly, extractable organic matter (EOM) was obtained by extracting freeze-dried soil (1.5 g) using an accelerated solvent extractor (ASE 350, Dionex) with dichloromethane (130 $\left.{ }^{\circ} \mathrm{C}, 100 \mathrm{bar}, 10 \mathrm{~min}\right)$. Molecular sulfur and residual water were removed by adding to the extraction cells activated copper powder $(2 \mathrm{~g})$ and sodium sulfate $(2 \mathrm{~g})$, respectively. The extract volume (c.a. $40 \mathrm{~mL}$ ) was reduced to $20 \mathrm{~mL}$ by solvent evaporation under a gentle nitrogen stream. An aliquot $(3 \mathrm{~mL})$ was transferred into preweighed vials. The EOM content was determined by weighing the vial after solvent evaporation to dryness.

\subsubsection{PAC quantification}

Quantification of the 16 regulatory PAHs, perylene, 11 O-PACs and 5 N-PACs (Table S2) was carried out using internal calibration. An internal PAH standard mix of $\left[{ }^{2} \mathrm{H}_{8}\right]$ naphthalene, $\left[{ }^{2} \mathrm{H}_{10}\right]$ acenaphthene, 
$\left[{ }^{2} \mathrm{H}_{10}\right]$ phenanthrene, $\left[{ }^{2} \mathrm{H}_{12}\right]$ chrysene, $\left[{ }^{2} \mathrm{H}_{12}\right]$ perylene, $\left(\mathrm{Cluzeau}^{\oplus}, 20 \mu \mathrm{L}\right.$ at $16 \mathrm{~g} / \mathrm{mL}$ ) was added to $80 \mu \mathrm{L}$ of the $17 \mathrm{~mL}$ remaining of the EOM before being injected in a gas chromatograph coupled with a mass spectrometer (GC-MS). For each quantified compound, internal calibration curve was drawn with six concentrations $(0.3,0.9,1.5,3,6$ and $9 \mu \mathrm{g} / \mathrm{mL})$. The instrument settings and the methods used for analyses were previously reported [25] and are detailed in the Supplementary Data.

\subsection{Microbial analyses}

\subsubsection{DNA extraction}

Genomic DNA was extracted from of freeze-dried soil (0.5 g) using Fast DNA Spin Kit for Soils (MP Biomedicals) following manufacturer instruction. DNA was eluted in $100 \mu \mathrm{L}$ DES and its concentration and quality was determined using spectrophotometer UV-1800 (Shimadzu) equipped with a TrayCell adaptor for micro-volumes (Hellma). DNA was stored at $-20^{\circ} \mathrm{C}$ until further analyses.

\subsubsection{Real-time PCR quantification of fungi, bacteria and functional bacteria}

The genomic DNA was used to quantify the total bacteria and fungi using 968F/1401R [26] and Fung5f/FF390r $[27,28]$ primers targeting bacterial $16 \mathrm{~S}$ rRNA and fungal $18 \mathrm{~S}$ rRNA genes, respectively. Functional genes, i.e. PAH-ring hydroxylating dioxygenase genes from gram negative (Gram-) and positive (Gram+) bacteria, were quantified using previously published primers, i.e., PAH-RHDa GN F/R, PAH-RHD $\alpha$ GP F/R [29]. Real-time PCR quantifications were performed using CFX96 C1000 ${ }^{\text {TM }}$ Real Time sytem (Bio-Rad). Details on the amplification reactions are given in the Supplementary Data.

\subsection{Statistical analyses}

Statistical analyses were performed using XLStat version2015.1.03. Significant differences of parameters among the three soils or during the incubation period for one soil were detected with oneway ANOVA $(p<0.05)$ followed by Newman-Keuls post-hoc test. Comparison of all samples based on organic and microbial parameters was done through principal component analysis (PCA) based on Pearson correlation. 


\section{Results}

\subsection{Initial samples}

Agronomic parameters of the gas and coking plant soils were close with 25 and $30 \mathrm{C} / \mathrm{N}, 5$ and $17 \mathrm{~g} / \mathrm{kg}$ carbonate content and $0.092 \mathrm{and} 0.059 \mathrm{~g} / \mathrm{kg}$ available phosphorus content, respectively (TableS1). The three soils exhibited $\mathrm{pH}$ values comprised between 7.5 and 7.8. The wood-treating facility soil showed higher $\mathrm{C} / \mathrm{N}$, organic matter and carbonate contents and much lower available phosphorus than the other soils (Table S1). The specific area was of $9.8,4.6$ and $2.1 \mathrm{~m}^{2} / \mathrm{g}$ for the coking plant, the gas plant and the wood-treating facility soils, respectively. The organic characteristics of the soils varied with the sample origin (Table 1). Gas plant and coking plant soils exhibited similar properties with 3-6\% TOC, $11 \mathrm{mg} / \mathrm{g}$ EOM, $1200 \mu \mathrm{g} / \mathrm{g}$ PAHs, and less than $100 \mu \mathrm{g} / \mathrm{g}$ O- and N-PACs. Wood-treating facility soil showed higher values of TOC, 8 times more EOM and 10 times more PAH content with high concentrations of O- and N-PACs. Differences in the low molecular weight PAH over high molecular weight $\mathrm{PAH}$ ratio (LMW/HMW) reflected differences in $\mathrm{PAH}$ distribution. The gas plant soil was dominated by 3- and 4-ring PAHs (Table 2). The coking plant soil presented about the same concentrations in LMW and HMW PAHs (Table 3) and fluoranthene and pyrene largely dominated the PAH distribution of the wood-treating facility soil (Table 4).

Table 1: Total organic carbon (TOC), extractable organic matter (EOM) and polycyclic aromatic compound (PAC) concentrations. Letters indicate significant statistical differences (one-way Anova and Neuman-Keuls post-hoc test, $\mathrm{p}<0.05)$ among soils.

\begin{tabular}{lrrr}
\hline & Gas plant & Coking plant & \multicolumn{1}{c}{$\begin{array}{c}\text { Wood-treating } \\
\text { facility }\end{array}$} \\
\hline TOC $(\%)$ & $3.34 \pm 0.04^{\mathrm{C}}$ & $6.52 \pm 0.16^{\mathrm{B}}$ & $17.19 \pm 0.06^{\mathrm{A}}$ \\
EOM $(\mathrm{mg} / \mathrm{g})$ & $11.9 \pm 1.8^{\mathrm{B}}$ & $10.7 \pm 0.4^{\mathrm{B}}$ & $83.5 \pm 0.5^{\mathrm{A}}$ \\
$\Sigma 17 \mathrm{PAHs}^{1}(\mu \mathrm{g} / \mathrm{g})$ & $1229 \pm 42^{\mathrm{B}}$ & $1161 \pm 56^{\mathrm{B}}$ & $14344 \pm 1836^{\mathrm{A}}$ \\
$\Sigma 11 \mathrm{O}-\mathrm{PACs}^{2}(\mu \mathrm{g} / \mathrm{g})$ & $91.9 \pm 7.5^{\mathrm{B}}$ & $129 \pm 6.6^{\mathrm{B}}$ & $2051 \pm 297^{\mathrm{A}}$ \\
$\Sigma 5 \mathrm{~N}-\mathrm{PACs}^{3}(\mu \mathrm{g} / \mathrm{g})$ & $17.3 \pm 1.5^{\mathrm{B}}$ & $8.0 \pm 1.6^{\mathrm{B}}$ & $73.5 \pm 9.9^{\mathrm{A}}$ \\
LMW/HMW PAHs $^{4}$ & $3.5 \pm 0.2^{\mathrm{B}}$ & $1.4 \pm 0.1^{\mathrm{B}}$ & $286 \pm 89^{\mathrm{A}}$ \\
\hline
\end{tabular}

${ }^{1}$ Sum of the 16 regulated PAHs and perylene

2 Sum of oxygenated PAC: dibenzofuran, $9 \mathrm{H}$-fluorenone, perinaphthenone, 9,10-anthraquinone, cyclopenta[def]phenanthrone, 2-methylanthracene-9,10-dione, benz[a]fluorenone, 1,9-benz-10-anthrone, benz $[a]$ anthracene-7,12-dione, naphthacene-5,12-dione and benzo[cd]pyrenone

${ }^{3}$ Sum of nitrogenated PAC: quinoline, benzo[ $h$ ]quinoline, acridine and carbazole

${ }^{4}$ Sum of naphthalene to chrysene over sum of benzo[b]fluoranthene to benzo[ $\left.\mathrm{ghi}\right]$ perylene

\subsection{Mineralization}


The soil organic carbon mineralization was monitored during the experiment by measuring the produced $\mathrm{CO}_{2}$. Same trends were observed for the gas plant and the wood-treating facility soils (Fig. 1a) with a significant $\mathrm{CO}_{2}$ production during the first 20 days, then a slowdown appeared for the gas plant soil while the mineralization continued for the wood-treating facility soil until the $60^{\text {th }}$ day and slowed down afterward, until the end of the bioslurry. For the coking plant soil, after a 10-day lag phase, the $\mathrm{CO}_{2}$ production started with a slower linear slope than for the two other soils (Fig. $1 \mathrm{~b}$ ). Discrepancies in the proportion of mineralized organic carbon were observed according to the soil origin. At the end of the experiment about 10 and $14 \%$ of TOC were mineralized for the gas plant and wood-treating facility soils, respectively, whereas this value was less than $1 \%$ for the coking plant soil.
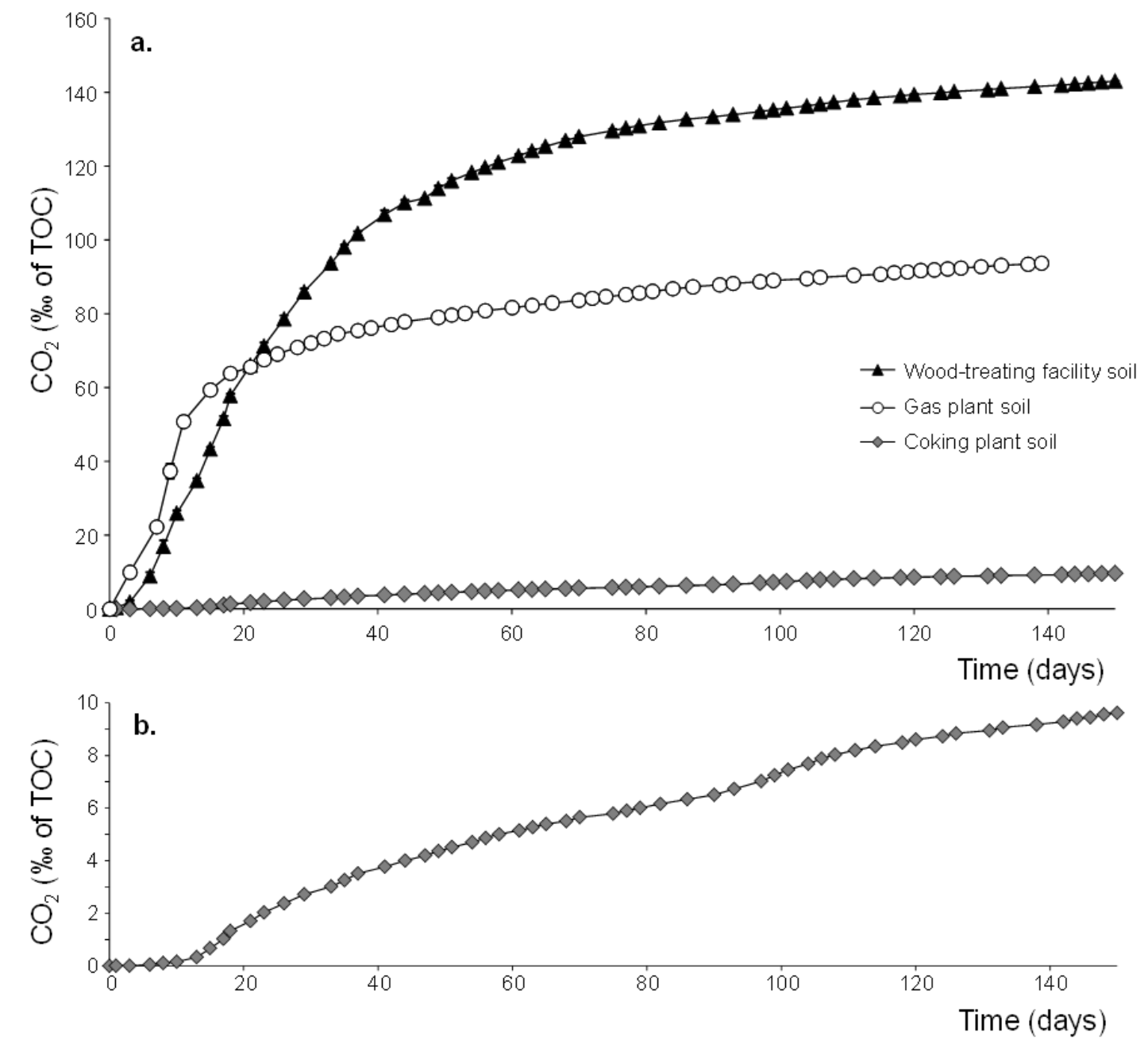

Figure 1: $\mathrm{CO}_{2}$ released during the microbial incubation a) of the three soils ( $n=3 \pm S D$ ) and b) zoomed portion for the coking plant soil. 
Table 2: Polycyclic aromatic compound (PAC) concentrations in the initial gas plant soil and after 1.5, 3 and 5 months of microbial incubation $(n=3, \pm S D)$. Letters indicate significant statistical differences (one-way Anova and Neuman-Keuls post-hoc test, $\mathrm{p}<0.05)$ during time.

\begin{tabular}{|c|c|c|c|c|}
\hline & Initial & 1.5 months & 3 months & 5 months \\
\hline \multicolumn{5}{|l|}{ PAHs } \\
\hline Naphthalene & $31.4 \pm 1.9^{\mathrm{A}}$ & $2.1 \pm 3.6^{\mathrm{B}}$ & $5.1 \pm 0.2^{B}$ & $4.6 \pm 0.5^{\mathrm{B}}$ \\
\hline Acenaphthylene & $50.9 \pm 1.7^{\mathrm{A}}$ & $35.4 \pm 1.6^{\mathrm{B}}$ & $23.3 \pm 0.9^{c}$ & $24.1 \pm 2.6^{C}$ \\
\hline Acenaphthene & $18.2 \pm 0.6^{A}$ & $0.3 \pm 0.3^{B}$ & n.d. ${ }^{B}$ & n.d. ${ }^{B}$ \\
\hline Fluorene & $63.1 \pm 1.9^{\mathrm{A}}$ & $1.2 \pm 0.5^{B}$ & n.d. ${ }^{B}$ & $0.9 \pm 0.1^{\mathrm{B}}$ \\
\hline Phenanthrene & $218 \pm 5.7^{A}$ & $5.2 \pm 0.5^{B}$ & $4.2 \pm 0.3^{B}$ & $4.2 \pm 0.5^{B}$ \\
\hline Anthracene & $67.5 \pm 1.7^{\mathrm{A}}$ & $11.8 \pm 0.6^{\mathrm{B}}$ & $6.3 \pm 0.3^{C}$ & $6.6 \pm 0.9^{c}$ \\
\hline Fluoranthene & $217 \pm 4.3^{\mathrm{A}}$ & $22.0 \pm 1.1^{\mathrm{B}}$ & $16.8 \pm 1.5^{\mathrm{C}}$ & $14.1 \pm 2.0^{C}$ \\
\hline Pyrene & $159 \pm 3.7^{A}$ & $20.7 \pm 0.6^{\mathrm{B}}$ & $16.4 \pm 0.7^{c}$ & $12.8 \pm 1.3^{C}$ \\
\hline Benz $[a]$ anthracene & $81.8 \pm 1.8^{\mathrm{A}}$ & $14.0 \pm 0.7^{B}$ & $12.2 \pm 0.3^{\mathrm{BC}}$ & $15.8 \pm 2.2^{\mathrm{C}}$ \\
\hline Chrysene & $49.1 \pm 8.5^{\mathrm{A}}$ & $11.9 \pm 0.4^{B}$ & $8.1 \pm 0.4^{B}$ & $11.6 \pm 1.3^{\mathrm{B}}$ \\
\hline Benzo $[b]$ fluoranthene & $43.8 \pm 19.9$ & $52.1 \pm 5.8$ & $35.9 \pm 9.9$ & $36.5 \pm 2.4$ \\
\hline Benzo[k]fluoranthene & $33.6 \pm 0.9^{A}$ & $13.3 \pm 0.3^{\mathrm{B}}$ & $12.8 \pm 0.8^{\mathrm{B}}$ & $12.8 \pm 1.8^{\mathrm{B}}$ \\
\hline Benz $[a]$ pyrene & $69.4 \pm 2.1^{A}$ & $41.2 \pm 3.1^{B}$ & $35.8 \pm 4.1^{\mathrm{C}}$ & $30.2 \pm 1.0^{\mathrm{D}}$ \\
\hline Perylene & $18.9 \pm 0.4^{B}$ & $18.3 \pm 0.8^{B}$ & $19.9 \pm 0.3^{\mathrm{AB}}$ & $22.6 \pm 3.2^{\mathrm{A}}$ \\
\hline Indeno[1,2,3-cd]pyrene & $54.4 \pm 1.3^{\mathrm{A}}$ & $54.5 \pm 1.8^{\mathrm{A}}$ & $55.6 \pm 1.4^{\mathrm{A}}$ & $50.5 \pm 2.5^{B}$ \\
\hline Dibenz $[a, h]$ anthracene & $12.1 \pm 1.4^{\mathrm{A}}$ & $9.1 \pm 0.7^{\mathrm{B}}$ & $7.8 \pm 0.4^{B}$ & $7.3 \pm 1.1^{\mathrm{B}}$ \\
\hline Benzo[ghi]perylene & $41.1 \pm 1.6^{\mathrm{B}}$ & $41.1 \pm 0.6^{B}$ & $47.4 \pm 1.2^{\mathrm{A}}$ & $43.6 \pm 2.0^{\mathrm{B}}$ \\
\hline Sum of PAHs & $1229 \pm 42.4^{\mathrm{A}}$ & $354 \pm 9.7^{B}$ & $308 \pm 10.2^{B}$ & $298 \pm 12.9^{\mathrm{B}}$ \\
\hline \multicolumn{5}{|l|}{ Oxygenated-PACs } \\
\hline Dibenzofuran & $43.4 \pm 1.1^{\mathrm{A}}$ & $1.4 \pm 0.2^{B}$ & n.d. ${ }^{B}$ & $1.2 \pm 0.1^{\mathrm{B}}$ \\
\hline 9H-fluorenone & $5.6 \pm 0.6^{\mathrm{A}}$ & $0.2 \pm 0.2^{B}$ & n.d. ${ }^{B}$ & $0.6 \pm 0.1^{B}$ \\
\hline Perinaphthenone & $4.3 \pm 1.0^{\mathrm{A}}$ & $2.0 \pm 1.7^{\mathrm{B}}$ & n.d. ${ }^{B}$ & n.d. ${ }^{B}$ \\
\hline 9,10-Anthraquinone & $6.6 \pm 3.4^{\mathrm{A}}$ & $0.5 \pm 0.4^{B}$ & n.d. ${ }^{B}$ & $0.9 \pm 0.1^{\mathrm{B}}$ \\
\hline Cyclopenta[def]phenanthrone & $3.9 \pm 3.9$ & $4.7 \pm 0.5$ & n.d. & $2.0 \pm 0.5$ \\
\hline 2-Methylanthracene-9,10-dione & $3.8 \pm 1.6^{\mathrm{A}}$ & $1.1 \pm 1.0^{\mathrm{B}}$ & n.d. ${ }^{B}$ & n.d. ${ }^{B}$ \\
\hline Benz $[a]$ fluorenone & $8.2 \pm 0.8^{A}$ & $2.5 \pm 0.6^{\mathrm{C}}$ & $4.7 \pm 0.7^{B}$ & $2.5 \pm 0.5^{c}$ \\
\hline 1,9-Benz-10-anthrone & $6.3 \pm 0.1^{\mathrm{A}}$ & $4.4 \pm 0.2^{B}$ & $4.4 \pm 0.3^{B}$ & $4.2 \pm 0.6^{B}$ \\
\hline Benz[a]anthracene-7,12-dione & $2.9 \pm 0.6^{A}$ & $3.3 \pm 1.0^{A}$ & $4.2 \pm 0.1^{\mathrm{A}}$ & $1.8 \pm 0.2^{\mathrm{B}}$ \\
\hline Naphthacene-5,12-dione & $5.9 \pm 0.8^{A}$ & $3.8 \pm 0.7^{\mathrm{AB}}$ & $1.6 \pm 2.8^{B}$ & $2.3 \pm 0.6^{B}$ \\
\hline Benzo $[c d]$ pyrenone & $1.1 \pm 0.6^{c}$ & $1.0 \pm 0.7^{C}$ & $9.9 \pm 0.2^{\mathrm{A}}$ & $4.6 \pm 0.6^{\mathrm{B}}$ \\
\hline Sum of O-PACs & $91.9 \pm 7.5^{\mathrm{A}}$ & $25.0 \pm 1.1^{\mathrm{B}}$ & $24.8 \pm 4.1^{\mathrm{B}}$ & $20.0 \pm 2.0^{B}$ \\
\hline \multicolumn{5}{|l|}{ Nitrogenated-PACs } \\
\hline Quinoline & n.d. & n.d. & n.d. & n.d. \\
\hline Benzo[h]quinoline & $0.2 \pm 0.2$ & n.d. & n.d. & n.d. \\
\hline Acridine & $2.1 \pm 1.2^{\mathrm{A}}$ & $0.2 \pm 0.2^{B}$ & n.d. ${ }^{B}$ & n.d. ${ }^{B}$ \\
\hline Carbazole & $14.9 \pm 0.4^{\mathrm{A}}$ & $2.8 \pm 0.2^{B}$ & n.d. ${ }^{D}$ & $1.7 \pm 0.2^{C}$ \\
\hline Nitropyrene & $0.1 \pm 0.1$ & $0.1 \pm 0.1$ & n.d. & n.d. \\
\hline Sum of N-PACs & $17.3 \pm 1.5^{\mathrm{A}}$ & $3.0 \pm 0.3^{B}$ & n.d. ${ }^{\mathrm{C}}$ & $1.7 \pm 0.2^{B}$ \\
\hline \multicolumn{5}{|l|}{ Ratio } \\
\hline LMW/HMW PAHs ${ }^{*}$ & $3.5 \pm 0.2^{A}$ & $0.5 \pm 0.0^{B}$ & $0.4 \pm 0.0^{B}$ & $0.5 \pm 0.0^{B}$ \\
\hline
\end{tabular}

${ }^{*} \mathrm{LMW} / \mathrm{HMW}$ PAHs = sum of naphthalene to chrysene concentrations over sum of benzo[ $\left.b\right]$ fluoranthene to benzo[ghi]perylene concentrations

n.d. not detected (under the detection limit)

\subsection{Evolution of the EOM content}


A decrease in the EOM content was observed for all soil samples during the experiment (Fig. 2). It mostly occurred over the first 1.5 months; afterward the EOM content remained fairly steady. The most important decrease was observed for the wood-treating facility soil with an EOM content going from 83.5 to $65.4 \mathrm{mg} / \mathrm{g}$. This decrease represented $22 \%$ of the initial EOM. The EOM decreased from 11.9 to $8.5 \mathrm{mg} / \mathrm{g}$ for the gas plant soil and from 10.7 to $8.9 \mathrm{mg} / \mathrm{g}$ for the coking plant soil, representing 29 and $17 \%$ of the initial EOM, respectively.

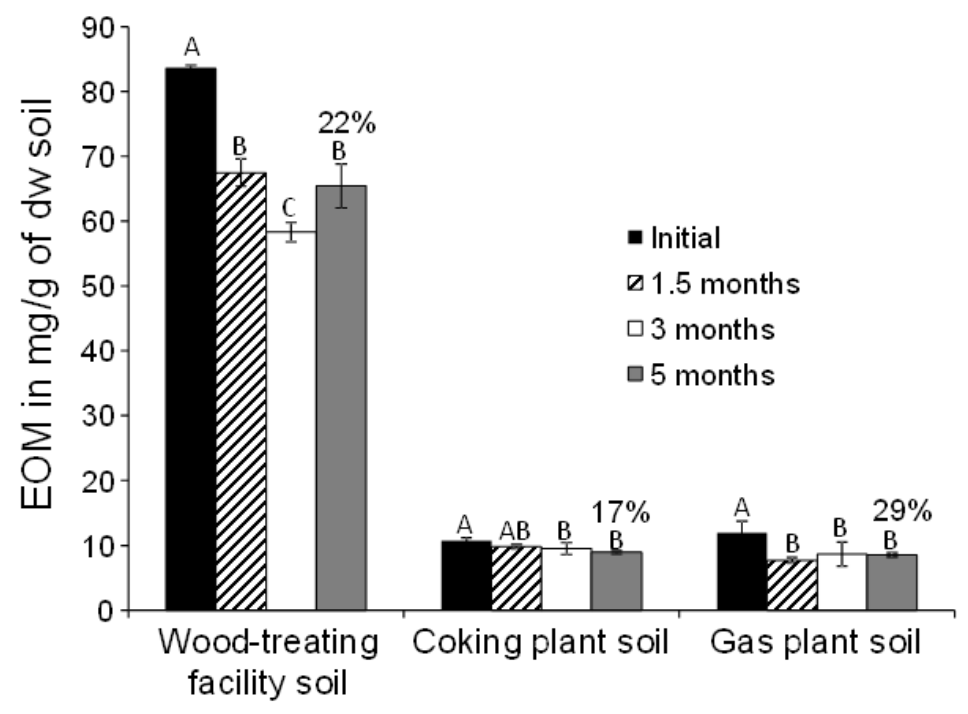

Figure 2: Extractable organic matter (EOM) of the initial soils and after 1.5, 3 and 5 months of microbial incubation $(n=3 ; \pm S D)$. Percentages indicate the EOM decrease rate after 5 months of experiment. Letters indicate significant statistical differences (one-way Anova and Neuman-Keuls post-hoc test, $\mathrm{p}<0.05$ ) during time.

\subsection{Evolution of the PAC contents}

\subsubsection{PAHs}

The PAH concentrations decreased during the bioslurry experiment for all soil samples. The most important decrease was observed for the wood-treating facility soil (Table 4) and reached $98 \%$ (from 14344 to $333 \mu \mathrm{g} / \mathrm{g}$ ). It principally occurred during the first 1.5 months and was mostly due to an important drop of fluoranthene and pyrene which represented $90 \%$ of the initial quantified PAHs. The gas plant soil PAH concentrations decreased from 1229 to $298 \mu \mathrm{g} / \mathrm{g}$, representing $76 \%$ of the initial PAH content (Table 2). The decrease was less important for the coking plant soil (34\%, Table 4). For all soils, the observed depletion involved only LMW compounds (up to 4-ring PAHs) as described by a decrease in the LMW/HMW ratios (Tables 2-4). The concentration of some LMW PAHs such as acenaphthylene 
and anthracene did not decrease to the same extent as other LMW compounds. They presented different degradation dynamics and the decrease in their concentration was more limited than their isomers or compounds presenting similar structure (acenaphthene and phenanthrene, respectively). In the coking plant and wood-treating facility soils, the decrease in acenaphtylene and anthracene was significant after3 months of incubation (i.e. for the 5-months sampling) whereas for the other LMW compounds the decrease was significant from the 1.5-months sampling.

\subsubsection{O-PACs and N-PACS}

A general decrease in O- and N-PAC concentrations was observed for the three soils (Tables 2-4). Generally the decrease was more important for LMW than for HMW O-PACs. Benzo[cd]pyrenone was produced during the experiment for all soils. Additionally benz[a]anthracene-7,12-dione concentration increased during the coking plant soil incubation. The decrease in O-PAC content was more important for the gas plant and wood-treating facility soils than for the coking plant soil. PAH and O-PAC degradation dynamics were different. After 5 months of experiment, the reduction rate of the quantified O-PACs was similar to the PAHs in the gas plant and the wood-treating facility soils and was higher for the coking plant soil. For the gas plant soil, similar dynamic of O-PAC and PAH degradation occurred during the first 1.5 months while for the coking plant soil a gradual decrease occurred throughout the experiment. On the contrary, for the wood-treating facility soil, most of the decrease in PAH concentrations occurred during the first 1.5 months whereas an important decrease in the OPAC concentrations still occurred between 1.5 and 3 months. The N-PACs, initially representing a small fraction of the PACs in the three soils, decreased during the experiment. 
Table 3: Polycyclic aromatic compound (PAC) concentrations in the initial coking plant soil and after 1.5, 3 and 5 months of microbial incubation $(n=3, \pm S D$ ). Letters indicate significant statistical differences (one-way Anova and Neuman-Keuls post-hoc test, $p<0.05$ ) during time.

\begin{tabular}{|c|c|c|c|c|}
\hline & Initial & 1.5 months & 3 months & 5 months \\
\hline \multicolumn{5}{|l|}{ PAHs } \\
\hline Naphthalene & $38.2 \pm 2.2^{\mathrm{A}}$ & $24.8 \pm 1.3^{\mathrm{B}}$ & $23.8 \pm 6.2^{\mathrm{B}}$ & $17.8 \pm 0.9^{B}$ \\
\hline Acenaphthylene & $45.6 \pm 2.3^{A}$ & $49.5 \pm 2.2^{\mathrm{A}}$ & $52.8 \pm 12.7^{A}$ & $28.1 \pm 2.0^{B}$ \\
\hline Acenaphthene & $23.7 \pm 1.3^{\mathrm{A}}$ & $10.6 \pm 0.7^{B}$ & $9.8 \pm 2.7^{B}$ & $6.5 \pm 0.2^{C}$ \\
\hline Fluorene & $20.0 \pm 1.1^{\mathrm{A}}$ & $9.7 \pm 0.7^{B}$ & $9.0 \pm 2.7^{B}$ & $4.5 \pm 0.3^{C}$ \\
\hline Phenanthrene & $84.5 \pm 4.0^{\mathrm{A}}$ & $34.5 \pm 3.0^{B}$ & $30.6 \pm 8.1^{\mathrm{BC}}$ & $22.2 \pm 1.7^{c}$ \\
\hline Anthracene & $36.7 \pm 1.6^{A}$ & $29.2 \pm 1.3^{\mathrm{A}}$ & $31.8 \pm 7.4^{\mathrm{A}}$ & $12.5 \pm 1.2^{\mathrm{B}}$ \\
\hline Fluoranthene & $160 \pm 6.3^{A}$ & $99.7 \pm 7.7^{\mathrm{B}}$ & $89.3 \pm 23.6^{\mathrm{BC}}$ & $70.6 \pm 4.5^{c}$ \\
\hline Pyrene & $122 \pm 5.3^{A}$ & $82.3 \pm 7.6^{B}$ & $75.3 \pm 21.8^{B}$ & $60.6 \pm 4.8^{B}$ \\
\hline Benz $[a]$ anthracene & $91.4 \pm 3.8^{\mathrm{A}}$ & $64.1 \pm 4.9^{B}$ & $59.2 \pm 14.9^{B}$ & $47.5 \pm 2.3^{B}$ \\
\hline Chrysene & $51.3 \pm 6.1^{A}$ & $29.2 \pm 3.9^{B}$ & $28.4 \pm 6.4^{B}$ & $36.0 \pm 1.1^{\mathrm{B}}$ \\
\hline Benzo[b]fluoranthene & $130 \pm 19.5^{A}$ & $124 \pm 9.6^{A}$ & $58.9 \pm 43.7^{B}$ & $89.2 \pm 3.2^{\mathrm{AB}}$ \\
\hline Benzo[k]fluoranthene & $53.2 \pm 1.8$ & $47.3 \pm 3.0$ & $44.0 \pm 10.6$ & $40.5 \pm 2.8$ \\
\hline Benz $[a]$ pyrene & $82.8 \pm 2.7$ & $80.2 \pm 4.0$ & $79.3 \pm 18.5$ & $71.4 \pm 2.5$ \\
\hline Perylene & $24.2 \pm 1.0$ & $26.2 \pm 1.0$ & $29.1 \pm 6.3$ & $27.5 \pm 1.9$ \\
\hline Indeno[1,2,3-cd]pyrene & $98.0 \pm 4.0$ & $105 \pm 3.1$ & $113 \pm 21.7$ & $113 \pm 8.5$ \\
\hline Dibenz $[a, h]$ anthracene & $25.4 \pm 1.2$ & $26.8 \pm 0.9$ & $28.1 \pm 6.4$ & $23.5 \pm 2.7$ \\
\hline Benzo[ghi]perylene & $74.1 \pm 3.6$ & $80.3 \pm 3.0$ & $84.5 \pm 18.5$ & $89.1 \pm 4.4$ \\
\hline Sum of PAHs & $1161 \pm 55.6^{A}$ & $923 \pm 39.1^{B}$ & $847 \pm 182^{\mathrm{B}}$ & $761 \pm 40.1^{\mathrm{B}}$ \\
\hline \multicolumn{5}{|l|}{ Oxygenated-PACs } \\
\hline Dibenzofuran & $19.2 \pm 1.1^{\mathrm{A}}$ & $9.5 \pm 0.8^{B}$ & $8.7 \pm 2.4^{\mathrm{B}}$ & $6.0 \pm 0.3^{C}$ \\
\hline 9H-fluorenone & $25.6 \pm 1.4^{\mathrm{A}}$ & $15.0 \pm 0.5^{B}$ & $14.2 \pm 3.7^{B}$ & $10.7 \pm 0.9^{B}$ \\
\hline Perinaphthenone & $3.1 \pm 0.3^{\mathrm{AB}}$ & $3.3 \pm 0.1^{\mathrm{A}}$ & $2.9 \pm 0.0^{\mathrm{B}}$ & n.d. ${ }^{C}$ \\
\hline 9,10-Anthraquinone & $16.5 \pm 0.7^{A}$ & $6.6 \pm 0.3^{B}$ & $5.7 \pm 1.4^{\mathrm{B}}$ & $5.8 \pm 0.2^{B}$ \\
\hline Cyclopenta[def]phenanthrone & $19.8 \pm 1.1^{\mathrm{A}}$ & $16.0 \pm 1.0^{B}$ & $12.7 \pm 4.1^{\mathrm{B}}$ & n.d. ${ }^{c}$ \\
\hline 2-Methylanthracene-9,10-dione & $2.2 \pm 1.0$ & $1.9 \pm 0.4$ & $1.7 \pm 0.1$ & $1.3 \pm 1.1$ \\
\hline Benz $[a]$ fluorenone & $13.4 \pm 0.8^{\mathrm{A}}$ & $8.7 \pm 0.9^{B}$ & $7.3 \pm 2.3^{B}$ & $8.9 \pm 0.3^{B}$ \\
\hline 1,9-Benz-10-anthrone & $10.6 \pm 0.7^{A}$ & $10.1 \pm 0.5^{\mathrm{A}}$ & $8.8 \pm 2.2^{\mathrm{AB}}$ & $6.8 \pm 0.4^{B}$ \\
\hline Benz[a]anthracene-7,12-dione & $2.8 \pm 0.1^{\mathrm{B}}$ & $2.8 \pm 0.1^{B}$ & $2.8 \pm 0.1^{\mathrm{B}}$ & $4.0 \pm 0.1^{\mathrm{A}}$ \\
\hline Naphthacene-5,12-dione & $5.5 \pm 0.2$ & $5.7 \pm 0.3$ & $4.6 \pm 1.3$ & $4.7 \pm 0.1$ \\
\hline Benzo $[c d]$ pyrenone & $10.5 \pm 2.4$ & $13.2 \pm 0.6$ & $10.6 \pm 4.9$ & $16.2 \pm 0.5$ \\
\hline Sum of O-PACs & $129 \pm 6.6^{A}$ & $92.8 \pm 4.5^{B}$ & $80.0 \pm 21.6^{\mathrm{BC}}$ & $64.3 \pm 1.8^{C}$ \\
\hline \multicolumn{5}{|l|}{ Nitrogenated-PACs } \\
\hline Quinoline & n.d. & n.d. & n.d. & n.d. \\
\hline Benzo[h]quinoline & n.d. & n.d. & n.d. & n.d. \\
\hline Acridine & $0.0 \pm 0.1$ & $0.1 \pm 0.1$ & $0.1 \pm 0.1$ & n.d. \\
\hline Carbazole & $7.2 \pm 0.5^{\mathrm{A}}$ & $4.5 \pm 0.4^{B}$ & $4.2 \pm 1.2^{B}$ & n.d. ${ }^{c}$ \\
\hline Nitropyrene & $0.8 \pm 1.5$ & $0.1 \pm 0.1$ & n.d. & n.d. \\
\hline Sum of N-PACs & $8.0 \pm 1.6^{\mathrm{A}}$ & $4.7 \pm 0.4^{B}$ & $4.3 \pm 1.1^{\mathrm{B}}$ & n.d. ${ }^{\mathrm{C}}$ \\
\hline \multicolumn{5}{|l|}{ Ratio } \\
\hline LMW/HMW PAHs ${ }^{*}$ & $1.4 \pm 0.1^{\mathrm{A}}$ & $0.9 \pm 0.1^{\mathrm{B}}$ & $0.9 \pm 0.1^{B}$ & $0.7 \pm 0.0^{C}$ \\
\hline
\end{tabular}

\footnotetext{
${ }^{*} \mathrm{LMW} / \mathrm{HMW}$ PAHs = sum of naphthalene to chrysene concentrations over sum of benzo[ $b$ ]fluoranthene to benzo[ghi]perylene concentrations n.d. not detected (under the detection limit)
}

\subsection{Abundance of fungi, bacteria and PAH degraders}


At the beginning of the bioslurry experiment, fungi were not detected in the coking plant soil although they were found in the wood-treating facility and the gas plant soils (ca 5.106 and 2.107 18S rDNA copies/g dw soil, respectively Table 5). The bacterial density was high in the three soils (ca from 4.105 to 1.109 16S rDNA copies/g dw soil). PAH-degraders were present in the three soils (Table 5). Woodtreating facility and coking plant soils contained high percentage of Gram+ PAH-degraders, and GramPAH-degraders were ten times less abundant, while they were dominant in gas plant soil. All along the bioslurry, the abundance of fungi decreased in the gas plant soil and increased in the coking plant soil while it remained constant in the wood-treating facility soil (though not detected after 1.5 months, Table 5). On the contrary, the abundance of total bacteria increased for the three soils during the experiment. Abundance of Gram+ PAH-degraders increased for the three soils and their percentage, relative to the total bacteria, stayed relatively constant. The behavior of Gram- PAH-degraders was different depending on the soil, their abundance and percentage decreased in the wood-treating facility soil, their abundance increased and percentage remained constant in the coking plant soil and their abundance increased and then decreased while their percentage decreased in the gas plant soil.
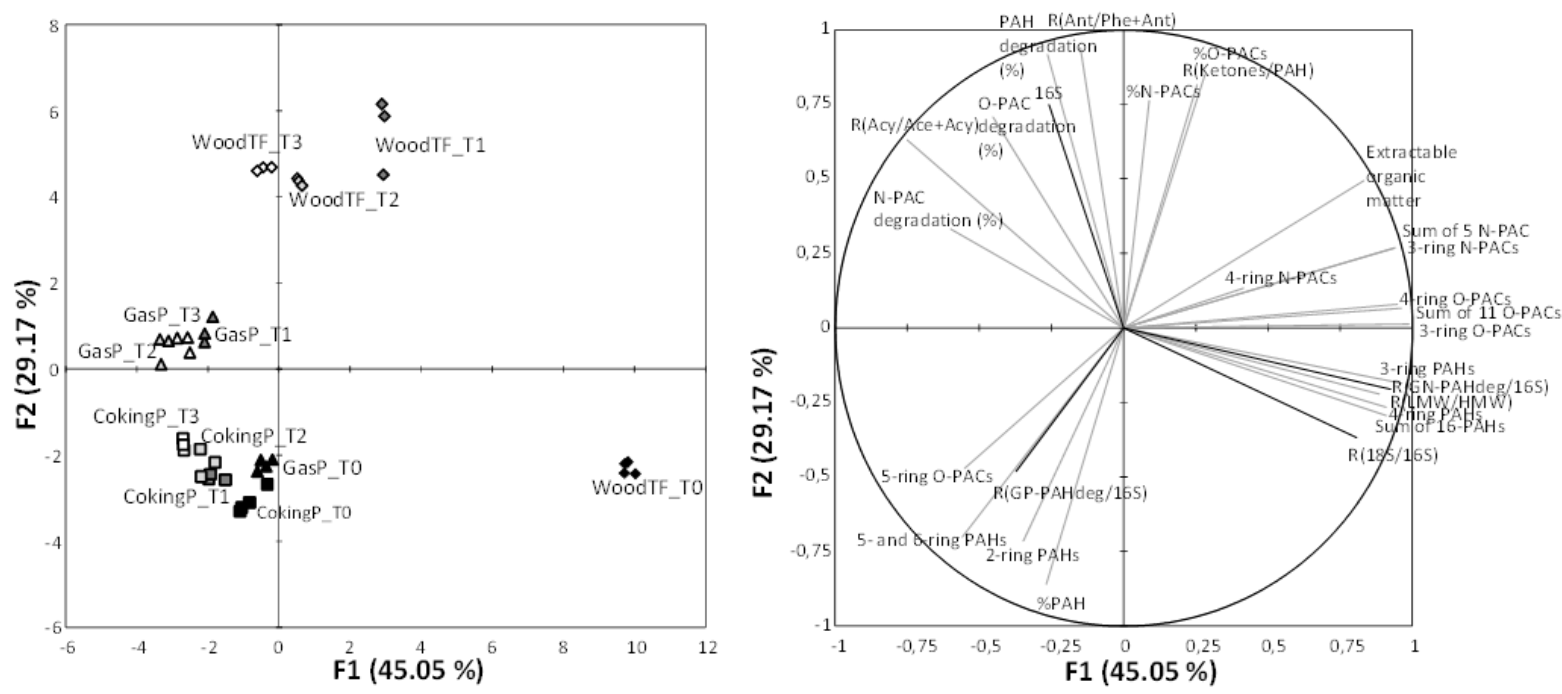

Figure 3: Principal component analysis (PCA) and correlation circle, based on organic and microbial parameters (grey and black vectors, respectively) for the three soils (wood-treating facility, WoodTF; coking plant, CokingP; and gas plant, GasP) at the four sampling times (T0, T1, T2 and T3). Abbreviations on the correlation circle correspond to $\mathrm{R}(\mathrm{LMW} / \mathrm{HMW})$ : ratio of low molecular weight over high molecular weight $\mathrm{PAHs}$; $\mathrm{R}(\mathrm{ketones} / \mathrm{PAH})$ : ratio of ketones over $16 \mathrm{PAH}$ content; $\mathrm{R}(\mathrm{Ant} / \mathrm{Phe}+\mathrm{Ant})$ : ratio of anthracene over sum of phenanthrene and anthracene contents; $\mathrm{R}(\mathrm{Acy} / \mathrm{Ace}+\mathrm{Acy})$ : ratio of acenaphthylene over sum of acenaphthene and acenaphthylene contents; \%PAH, \%O-PAC and \%N-PAC: percentage of each class of compounds (sum =100\%); 16S: abundance of bacterial 16S rDNA genes; R(18S/16S), R(GN-PAH-deg/16S), R(GP-PAH-deg/16S): ratio of fungal 18S rDNA gene, and PAH-RHDa from Gram negative and Gram positive bacteria over 16S rDNA gene abundance. 
Table 4: Polycyclic aromatic compound (PAC) concentrations in the initial wood-treating facility soil and after $1.5,3$ and 5 months of microbial incubation $(n=3, \pm S D$ ). Letters indicate significant statistical differences (oneway Anova and Neuman-Keuls post-hoc test, $p<0.05$ ) during time.

\begin{tabular}{|c|c|c|c|c|}
\hline & Initial & 1.5 months & 3 months & 5 months \\
\hline \multicolumn{5}{|l|}{ PAHs } \\
\hline Naphthalene & n.d. & n.d. & n.d. & n.d. \\
\hline Acenaphthylene & $106 \pm 9.9^{A}$ & $95.7 \pm 13.1^{\mathrm{A}}$ & $91.6 \pm 5.7^{A}$ & $52.1 \pm 5.3^{\mathrm{B}}$ \\
\hline Acenaphthene & $206 \pm 21.3^{\mathrm{A}}$ & $5.3 \pm 0.6^{\mathrm{B}}$ & $4.3 \pm 0.5^{\mathrm{B}}$ & n.d. ${ }^{B}$ \\
\hline Fluorene & $113 \pm 11.0^{A}$ & $9.4 \pm 1.1^{\mathrm{B}}$ & $8.1 \pm 2.1^{B}$ & $7.2 \pm 0.6^{B}$ \\
\hline Phenanthrene & $619 \pm 46.2^{A}$ & $22.9 \pm 2.2^{B}$ & $19.6 \pm 1.6^{\mathrm{B}}$ & $16.7 \pm 2.0^{B}$ \\
\hline Anthracene & $255 \pm 22.5^{A}$ & $211 \pm 17.2^{\mathrm{B}}$ & $203 \pm 11.8^{B}$ & $107 \pm 13.8^{C}$ \\
\hline Fluoranthene & $7826 \pm 1103^{A}$ & $120 \pm 77.2^{\mathrm{B}}$ & $54.5 \pm 6.2^{\mathrm{B}}$ & $40.1 \pm 5.1^{B}$ \\
\hline Pyrene & $5072 \pm 756^{A}$ & $518 \pm 530^{B}$ & $79.3 \pm 10.1^{B}$ & $41.2 \pm 2.8^{B}$ \\
\hline Benz[a]anthracene & $48.6 \pm 4.9^{A}$ & $15.9 \pm 8.8^{B}$ & $9.7 \pm 2.9^{B}$ & $5.1 \pm 0.2^{\mathrm{B}}$ \\
\hline Chrysene & $45.0 \pm 8.0^{A}$ & $20.2 \pm 2.9^{B}$ & $7.0 \pm 4.6^{C}$ & n.d. ${ }^{C}$ \\
\hline Benzo[b]fluoranthene & $24.1 \pm 13.0$ & $30.1 \pm 2.7$ & $25.3 \pm 1.5$ & $27.2 \pm 2.9$ \\
\hline Benzo[k]fluoranthene & $7.0 \pm 0.6^{\mathrm{B}}$ & $6.4 \pm 1.1^{\mathrm{B}}$ & $23.4 \pm 1.5^{\mathrm{A}}$ & $5.4 \pm 0.4^{B}$ \\
\hline Benz $[a]$ pyrene & $6.0 \pm 0.9^{B}$ & $5.8 \pm 0.9^{B}$ & $8.9 \pm 1.6^{\mathrm{A}}$ & $7.8 \pm 0.8^{\mathrm{AB}}$ \\
\hline Perylene & $1.2 \pm 1.1$ & n.d. & $1.6 \pm 0.8$ & $2.9 \pm 2.5$ \\
\hline Indeno[1,2,3-cd]pyrene & $7.8 \pm 2.0$ & $9.1 \pm 1.0$ & $9.7 \pm 0.8$ & $10.9 \pm 1.2$ \\
\hline Dibenz $[a, h]$ anthracene & $0.4 \pm 0.8$ & n.d. & n.d. & n.d. \\
\hline Benzo[ghi]perylene & $7.0 \pm 0.6$ & $6.9 \pm 1.1$ & $6.4 \pm 0.8$ & $8.8 \pm 1.4$ \\
\hline Sum of PAHs & $14344 \pm 1836^{\mathrm{A}}$ & $1077 \pm 502^{B}$ & $552 \pm 30.2^{B}$ & $333 \pm 37.9^{B}$ \\
\hline \multicolumn{5}{|l|}{ Oxygenated-PACs } \\
\hline Dibenzofuran & $28.3 \pm 2.8^{A}$ & $3.9 \pm 0.5^{B}$ & $3.8 \pm 0.4^{B}$ & n.d. ${ }^{C}$ \\
\hline 9H-fluorenone & $27.7 \pm 3.2^{\mathrm{A}}$ & $12.2 \pm 2.3^{B}$ & $13.2 \pm 0.9^{B}$ & $8.6 \pm 0.9^{B}$ \\
\hline Perinaphthenone & $25.1 \pm 8.1^{\mathrm{A}}$ & $15.5 \pm 1.1^{\mathrm{B}}$ & $14.8 \pm 0.4^{\mathrm{B}}$ & n.d. ${ }^{C}$ \\
\hline 9,10-Anthraquinone & $189 \pm 16.0^{\mathrm{A}}$ & $100 \pm 9.5^{B}$ & $78.2 \pm 6.6^{C}$ & $57.3 \pm 6.7^{\mathrm{D}}$ \\
\hline Cyclopenta[def]phenanthrone & $1504 \pm 308^{A}$ & $937 \pm 50.3^{B}$ & $155 \pm 20.4^{c}$ & $62.8 \pm 7.5^{c}$ \\
\hline 2-Methylanthracene-9,10-dione & $80.0 \pm 4.7^{\mathrm{A}}$ & $22.0 \pm 15.3^{B}$ & $8.6 \pm 0.9^{B}$ & $22.8 \pm 2.7^{B}$ \\
\hline Benz $[a]$ fluorenone & $80.2 \pm 8.6^{A}$ & $34.5 \pm 3.1^{B}$ & $10.5 \pm 5.2^{c}$ & $14.1 \pm 1.8^{C}$ \\
\hline 1,9-Benz-10-anthrone & $26.8 \pm 4.8^{A}$ & $22.1 \pm 0.9 a^{B}$ & $18.5 \pm 0.7^{B}$ & $12.8 \pm 1.3^{C}$ \\
\hline Benz[a]anthracene-7,12-dione & $28.1 \pm 4.0^{\mathrm{A}}$ & $21.5 \pm 0.6^{\mathrm{B}}$ & $14.2 \pm 1.0^{C}$ & $6.5 \pm 0.6^{\mathrm{D}}$ \\
\hline Naphthacene-5,12-dione & $61.7 \pm 3.2^{\mathrm{A}}$ & $57.5 \pm 5.9^{A}$ & $24.7 \pm 1.6^{\mathrm{B}}$ & $14.1 \pm 1.4^{C}$ \\
\hline Benzo $[c d]$ pyrenone & n.d.b & n.d. ${ }^{B}$ & n.d. ${ }^{B}$ & $4.4 \pm 0.1^{\mathrm{A}}$ \\
\hline Sum of O-PACs & $2051 \pm 297^{A}$ & $1227 \pm 40.5^{\mathrm{B}}$ & $342 \pm 17.5^{c}$ & $203 \pm 22.1^{C}$ \\
\hline \multicolumn{5}{|l|}{ Nitrogenated-PACs } \\
\hline Quinoline & n.d. & $0.3 \pm 0.5$ & n.d. & n.d. \\
\hline Benzo[h]quinoline & $2.7 \pm 2.3$ & n.d. & n.d. & n.d. \\
\hline Acridine & $24.6 \pm 3.4^{\mathrm{A}}$ & $6.9 \pm 0.6^{\mathrm{B}}$ & $6.2 \pm 0.4^{B}$ & $6.2 \pm 0.6^{B}$ \\
\hline Carbazole & $45.4 \pm 4.8^{A}$ & $38.7 \pm 4.5^{\mathrm{AB}}$ & $36.3 \pm 2.2^{\mathrm{B}}$ & $20.8 \pm 2.8^{C}$ \\
\hline Nitropyrene & $0.8 \pm 0.7$ & $1.6 \pm 1.4$ & n.d. & n.d. \\
\hline Sum of N-PACs & $73.5 \pm 9.9^{A}$ & $47.5 \pm 3.5^{B}$ & $42.5 \pm 2.6^{\mathrm{B}}$ & $26.9 \pm 3.5^{c}$ \\
\hline \multicolumn{5}{|l|}{ Ratio } \\
\hline LMW/HMW PAHs ${ }^{*}$ & $286 \pm 88.7^{A}$ & $17.5 \pm 8.5^{\mathrm{B}}$ & $6.4 \pm 0.2^{B}$ & $4.3 \pm 0.2^{B}$ \\
\hline
\end{tabular}

${ }^{*}$ LMW/HMW PAHs = sum of naphthalene to chrysene concentrations over sum of benzo[ $b$ ]fluoranthene to benzo[ghi]perylene concentrations

n.d. not detected (under the detection limit)

\subsection{Multivariate analysis}


Soils were compared based on organic and microbial properties measured during bioslurry experiment through a PCA explaining about $75 \%$ of the variability among samples, the first and the second PCA components accounting for $45 \%$ and $29 \%$ of variance, respectively (Fig. 3). Samples were relatively well separated according to their origin and the incubation duration. The initial soil from wood-treating facility appeared to be plotted separately from the other initial samples underlining important differences between those samples, with higher concentration of 3-4 ring PAHs, higher LMW/HMW ratio, higher total PAHs, O-and N-PAC concentrations and higher percentage of fungi relative to bacteria. The gas and coking plant soils were plotted very close on the PCA underlining their similarities such as higher HMW PAH concentration, higher relative proportion of PAHs compared to polar-PACs, and higher percent-age of Gram+ PAH-degrading bacteria. The incubated coking plant soils were plotted close to the initial samples indicating limited changes during the experiment in the parameters used to build the PCA. The location of the incubated gas plant soils in the PCA showed that more important changes in these parameters occurred during the first 1.5 months of the experiment followed by minor modifications. Wood-treating facility soil was subjected to important modification during the first 1.5 months of the incubation, and to a lesser extent until the end of the experiment.

\section{Discussion}

\subsection{Bioremediation efficiency according to soil origins}

Albeit the contamination origin in the soils can be considered as similar (coal and coal-tar by-products), different soil behaviors during the bioslurry experiment were observed. It was particularly noticeable for the coking and gas plant soils. Equivalent agronomic parameters indicated no, or limited impact of these factors on bioremediation efficiency. Both soils also exhibited similar organic characteristics in terms of TOC, EOM and PAC contamination however, their evolution during the experiment were quite different. The mineralization activity, the EOM decrease rate as well as the PAC degradation were more important in the gas plant soil than in the coking plant soil. These differences can be explained by difference of PAC, and especially PAH distribution. As previously mentioned, the PAH distribution in 
the gas plant soil was dominated by 3 - and 4-ring PAHs, whereas the coking plant soils presented higher proportion of HMW PAHs (5-ring PAHs). The fact that microbial communities preferentially degrade LMW PAHs [15] could then explain why bioremediation was more efficient on the gas plant soil than on the coking plant soil. A greater abundance of Gram- PAH-degrading bacteria was detected in the gas plant soil and could be involved in the more efficient LMW PAH degradation, because members of this functional group were described to be involved in 2- and 3-ring PAH degradation [30]. Moreover, previous studies have shown that Neuves-Maisons coking plant soil exhibits low level of PAH availability $[25,31-34]$ and that PAHs in the gas plant soil were more easily degraded than in the coking plant soil during chemical oxidation [25]. Moreover, the low PAH availability in the coking plant soil can also be linked to higher specific area (twice more than gas plant soil, Table S1) which offered more sorption sites for PAHs [35]. This higher PAH availability in the gas plant soil than in the coking plant soil could explain the higher bacterial biodegradation activity. The organic characteristics of the woodtreating facility soil were different from the other soils with much higher TOC, EOM, and PAC contents than in the other soils. This soil exhibited lower quality value of the measured agronomic parameters $(\mathrm{C} / \mathrm{N}$, available phosphorus). However the bioremediation was very efficient to degrade PAHs and other PACs indicating that these compounds were available for microorganisms. The measured agronomic parameters did not seem to be a major constrain for bioremediation efficiency, contrary to PAC availability. This high bioavailability can be related to the fact that the wood-treating site is still running and that the contamination is "fresh", in opposition to the aged contamination of the other soils.

\subsection{EOM degradation selectivity}

In comparison with the initial samples, the proportions of EOM remaining after the experiment were higher than the PAC proportions (Fig. S1), indicating a preferential PAC degradation over the other compounds found in EOM. For these soils inherited from coal-related activity, macromolecules and asphaltenes can represent a high proportion of the EOM [36,37]. As these fractions are often 
considered to be recalcitrant to biodegradation [38,39], they can account for the lower degradation

rate of the EOM compared to thePACs.

Table 5: Gene copy numbers of the $16 \mathrm{~S}$ rDNA, $18 \mathrm{~S}$ rDNA and the PAH-RHD $\alpha$ functional genes from Gram negative (GN) and Gram positive (GP) bacteria during the microbial incubation of the soils. Letters indicate significant statistical differences (one-way Anova and Neuman-Keuls post-hoc test, $p<0.05$ ) during time for one gene and one soil.

\begin{tabular}{|c|c|c|c|c|c|c|c|c|}
\hline \multirow{5}{*}{ 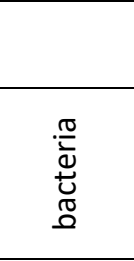 } & \multicolumn{2}{|c|}{ Gene copy number (g dw soil-1) } & \multicolumn{2}{|c|}{$\begin{array}{c}\text { Wood-treating } \\
\text { facility soil }\end{array}$} & \multicolumn{2}{|c|}{ Coking plant soil } & \multicolumn{2}{|c|}{ Gas plant soil } \\
\hline & \multirow{4}{*}{ 16S rDNA } & Initial & $9.67 \times 10^{8}$ & B & $3.77 \times 10^{5}$ & B & $1.90 \times 10^{8}$ & c \\
\hline & & 1.5 months & $2.91 \times 10^{9}$ & $A B$ & $1.42 \times 10^{7}$ & A & $2.34 \times 10^{9}$ & B \\
\hline & & 3 months & $3.59 \times 10^{9}$ & A & $1.81 \times 10^{8}$ & A & $2.48 \times 10^{9}$ & B \\
\hline & & 5 months & $3.49 \times 10^{9}$ & A & $2.56 \times 10^{8}$ & A & $4.96 \times 10^{9}$ & A \\
\hline \multirow{4}{*}{ 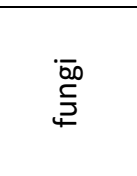 } & \multirow{4}{*}{ 18S rDNA } & Initial & $5.43 \times 10^{6}$ & & n.d. & & $2.13 \times 10^{7}$ & A \\
\hline & & 1.5 months & n.d. & & n.d. & & $3.06 \times 10^{5}$ & $A B$ \\
\hline & & 3 months & $4.56 \times 10^{5}$ & & $4.59 \times 10^{6}$ & A & $1.53 \times 10^{3}$ & c \\
\hline & & 5 months & $8.08 \times 10^{6}$ & & $3.83 \times 10^{5}$ & B & $7.71 \times 10^{4}$ & $\mathrm{BC}$ \\
\hline \multirow{8}{*}{ 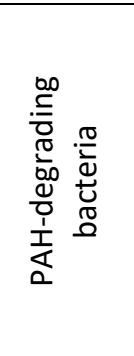 } & \multirow{4}{*}{ PAH-RHD $\alpha G P$} & Initial & $1.66 \times 10^{8}$ & B & $4.43 \times 10^{4}$ & C & $2.16 \times 10^{6}$ & B \\
\hline & & 1.5 months & $1.70 \times 10^{7}$ & c & $6.08 \times 10^{6}$ & B & $1.48 \times 10^{6}$ & B \\
\hline & & 3 months & $5.73 \times 10^{8}$ & A & $1.01 \times 10^{8}$ & A & $1.12 \times 10^{7}$ & A \\
\hline & & 5 months & $3.64 \times 10^{8}$ & A & $2.53 \times 10^{7}$ & $A B$ & $2.33 \times 10^{7}$ & A \\
\hline & \multirow{4}{*}{ PAH-RHD $\alpha G N$} & Initial & $2.59 \times 10^{7}$ & A & $9.74 \times 10^{3}$ & B & $7.11 \times 10^{7}$ & B \\
\hline & & 1.5 months & $4.57 \times 10^{7}$ & A & $1.67 \times 10^{6}$ & A & $2.73 \times 10^{8}$ & A \\
\hline & & 3 months & $7.12 \times 10^{6}$ & $A B$ & $4.29 \times 10^{6}$ & A & $3.23 \times 10^{7}$ & c \\
\hline & & 5 months & $1.20 \times 10^{6}$ & B & $1.74 \times 10^{5}$ & A & $6.38 \times 10^{7}$ & B \\
\hline \multirow{4}{*}{ 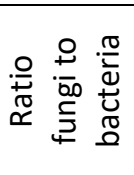 } & \multirow{4}{*}{$\% 18 S / 16 S$ rDNA } & Initial & 0.50 & & n.d. & & 11.00 & A \\
\hline & & 1.5 months & n.d. & & n.d. & & 0.01 & B \\
\hline & & 3 months & 0.02 & & 2.21 & A & 0.00 & B \\
\hline & & 5 months & 0.17 & & 0.11 & B & 0.00 & B \\
\hline \multirow{8}{*}{ 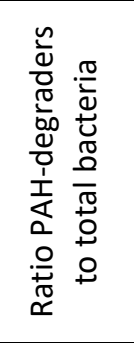 } & \multirow{4}{*}{$\begin{array}{c}\% \text { PAH-RHDaGP } \\
\text { to } 16 \mathrm{~S} \text { rDNA }\end{array}$} & Initial & 17.50 & A & 12.25 & B & 1.14 & A \\
\hline & & 1.5 months & 0.57 & B & 48.84 & A & 0.07 & B \\
\hline & & 3 months & 18.38 & A & 59.27 & A & 0.50 & B \\
\hline & & 5 months & 10.95 & $A B$ & 12.82 & B & 0.46 & B \\
\hline & \multirow{4}{*}{$\begin{array}{c}\% \text { PAH-RHD } \alpha G N \\
\text { to } 16 S \text { rDNA }\end{array}$} & Initial & 2.58 & A & 1.65 & $A B$ & 37.79 & A \\
\hline & & 1.5 months & 1.37 & $A B$ & 8.23 & A & 12.31 & B \\
\hline & & 3 months & 0.20 & B & 3.42 & $A B$ & 1.37 & c \\
\hline & & 5 months & 0.03 & B & 0.22 & B & 1.34 & c \\
\hline
\end{tabular}

n.d. not detected (under the detection limit)

\subsection{Degradation selectivity among PAHs}

During the bioremediation experiment PAC were not degraded equally. LMW PACs were more affected than HMW compounds. The degradation of three fused-ring PAHs and alkyl-PAHs was previously shown to be greater than for four fused-ring compounds [14]. As previously underlined, microorganisms preferentially degrade LMW compounds that can be used as sole source of carbon and energy $[40,41]$, contrary to HMW that are primarily biodegraded by co- metabolism [42]. However, difference in bioavailability can also explain these discrepancies. Indeed, several studies have pointed 
out that low degradation of HMW compounds is not necessarily caused by absence of microbial consortium able to degrade them but is also related to the lower bioavailability of HMW compounds [43-45] in relation to their physical-chemical properties. Among the LMW compounds, different behaviors were observed between isomers or compounds presenting close molecular weight. In this way, anthracene and acenaphthylene degradation rates were lower than the ones of phenanthrene and acenaphthene, even when the concentrations of the latter were higher. Such differences in biodegradation rates were observed in previous studies but were not discussed [36,46-49]. Difference of solubility, which is about 30 times higher for phenanthrene than for anthracene (1.15 and 0.0434 $\mathrm{mg} / \mathrm{L}$, respectively [50]) could explain higher degradation rate for the phenanthrene as it can be expressed by higher bioavailability to microorganisms. However it cannot explain the differences for the acenaphtene/acenaphthylene pair since acenaphthene solubility is about 4 times lower than acenaphthylene's (3.90 and $16.1 \mathrm{mg} / \mathrm{L}$, respectively [50]). Microbial degradation pathways of acenaphthylene and acenaphthene are not very well documented. They were described for Acinetobacter [51], Sphingomonas [52], Pseudomonas [53] and Rhizobium [54] strains. These studies show that for both compounds the initial attack occurs in the five-membered ring. The difference of structure between acenaphthene and acenaphthylene is on this five-membered ring with the presence of a double bond in the acenaphtylene. This double bond could confer on acenaphthylene a higher stability than acenaphthene resulting in lower biodegradability of acenaphthylene compared to acenaphthene. It is also known that the presence of other compounds (other PAHs or degradation products) can affect the mineralization rate of some PAHs. For instance, naphthalene and methylnaphthalene inhibited phenanthrene degradation by Pseudomonads [55]. Jones et al. [56] also showed that addition of some LMW PAHs inhibited the degradation of spiked benz[a]anthracene in contaminated soils due to a competitive inhibition of PAH metabolism that can occur when compounds are incubated together and more than one substrate is metabolized by the same enzymes.

\subsection{O-PAC dynamic}


Contrary to our observation, Lundstedt et al. [14] showed that O-PACs were biodegraded more slowly than the PAHs with the same number of fused-rings. The difference of degradation dynamic between PAHs and O-PACs in the wood-treating facility soil could be explained by an accumulation of PAH degradation by-products during the first 1.5 months. It is known that O-PACs can be produced as metabolites during biodegradation of PAHs $[5,14,17,18]$. This accumulation of O-PACs, produced from PAH degradation could then occur concomitantly with the degradation of O-PACs present in the initial contamination. As previously mentioned, most of the compound concentrations decreased during the experiment except for benzo[cd]pyrenone concentration which increased for all soils and benz [a]anthracene-7,12-dione concentration for the coking plant soil. Benz[a]anthracene-7,12-dione has been reported as a metabolite produced during benz $[a]$ anthracene degradation by Mycobacterium vanbaalenii strain PYR1, a Gram+ PAH-degrading bacteria $[57,58]$. In the coking plant soil, Gram+PAHdegraders were largely more represented than Gram- ones. The increase in benz $[a] a n t h r a c e n e-7,12-$ dione concentration could then be an indication of metabolite accumulation. To our knowledge there was no clear report in the literature of benzo[cd]pyrenone being a metabolite of PAH degradation but the increase in its concentration during the bioslurry experiment of a gas plant soil was already reported [14]. Considering its structure, it could result from the degradation of benzo[cd]pyrene, also known under the trivial name "olympicene", but this compound was not detected in the initial samples. As pointed out by Lundstedt et al. [14] the presence of PAH containing saturated carbon in six-membered ring make them more sensitive to oxidation, explaining the absence of benzo[cd]pyrene in the initial sample. Benzo[cd]pyrenone could then be implicated in the degradation pathway of another PAC.

\subsection{Evolution of microbial communities}

As previously mentioned, the gas plant and the wood-treating facility soils exhibit high level of PAH availability [25]. It did not seem to induce toxicity towards bacteria because their abundance increased in the soils during incubation. Previous works showed that PAH pre-exposure favors the development 
of microbial community able to degrade the contamination $[59,60]$ and that the PAH contamination level was correlated with abundance of PAH-degrading bacteria estimated by quantification of PAHRHD $\alpha$ genes[29]. The fungal population was poorly represented all along the experiment relative to bacteria. Such evolution in the microbial community was already reported [61] and indicates that bacteria were mostly responsible for PAC degradation. Our bioslurry conditions could potentially be less favorable to fungal development or activity. Indeed, it was previously highlighted that bacteria and fungi were favored, and that biodegradation efficiency was greater in soil than in slurry [48]. The bioremediation experiment seemed to transiently favor the PAH-degraders mostly during the first 1.5 months, and then the proportion of PAH-degraders relative to total bacteria tended to decrease. The occurrence of PAH-degrading bacteria was linked to higher PAC degradation at the beginning of the experiment. Among the potential PAH-degraders, Gram+ bacteria dominated in the coking plant and the wood-treating facility soils while Gram- bacteria dominated in the gas-plant soil. Most of the Gram+ PAH-degraders are known to be able to metabolize a wide range of compounds, including HMW PAHs [62], contrary to Gram- bacteria that were mainly described as LMW PAH-degraders. As previously mentioned, the coking plant soil exhibit low PAC bioavailability which can also promote the development of Gram + bacteria as they are known to have the potential to increase PAH bioavailability by forming biofilm on hydrophobic contaminants [63].

\section{Conclusion/Summary}

The effects of a bioslurry experiment on PAC contaminated soils were investigated by monitoring the soil organic characteristics and the microbial community abundances. The bioslurry experiment induced a decrease in the EOM and PAC contents with evidence of organic matter mineralization. The decrease in PAC concentrations was particularly effective in soils presenting the highest bioavailability. The PAC decrease was most likely due to bacterial degradation as it seems that compounds present in the initial soil or incubation conditions induced toxicity towards fungi. A selectivity of PAC degradation was observed between compounds due to their molecular weights or to their isomeric structure 
probably because of a difference in solubility and/or stability (presence of double bonds). This selectivity could be used as indicator of biodegradation process efficiency. The degradation of O-PACS was greater than PAHs, even if in the wood-treating facility soil O-PACs accumulated transiently before being degraded. However, some dead-end O-PACs (benzo $[c d]$ pyrenone) were produced during the bioremediation of the three soils without further degradation. It is worthwhile reminding that accumulation of toxic O-PACs could occur during on-site and in-situ soil bioremediation, especially because the conditions maximizing the microbial activity and the PAH degradation used in lab experiments are not necessarily encountered during field treatments. The potential O-PAC accumulation underlines the importance of broadening the range of monitored compounds, including these unregulated O-PACs presenting higher toxicity, solubility and mobility than PAHs, possibly impacting more widely the environment during remediation treatments.

\section{Acknowledgements}

We thank the GISFI (French Scientific Interest Group - Industrial Wasteland, www.gisfi.prd.fr). This work was financially supported by the French Environment and Energy Management Agency (ADEME) as a part of the European project SNOWMAN III. We thank the two anonymous reviewers whose constructive comments helped improving the quality of this paper.

\section{References}

[1] European Environmental Agency, http://www.eea.europa.eu/data-and-maps/figures/overview-ofcontaminants-affecting-soil-and-groundwater-in-europe. Accessed December 2013.

[2] L.H. Keith, W.A. Telliard, Priority pollutants I-a perspective view, Environ. Sci. Technol. 13 (1979) 416-423.

[3] P.L. Chesis, D.E. Levin, M.T. Smith, L. Ernster, B. Ames, Mutagenicity of quinones: pathways of metabolic activation and detoxification, Proc. Natl. Acad. Sci. U. S. A. 81 (1984) 1696-1700. 
[4] J.L. Durant, W.F. Busby Jr., A.L. Lafleur, B.W. Penman, C.L. Crespi, Human cell mutagenicity of oxygenated, nitrated and unsubstituted polycyclic aromatic hydrocarbons associated with urban aerosols, Mutat. Res.-Genet. Tox. 371 (1996) 123-157.

[5] S. Lundstedt, P.A. White, C.L. Lemieux, K.D. Lynes, I.B. Lambert, L. Öberg, P. Haglund, M. Tyskling, Sources, fate, and toxic hazards of oxygenated polycyclic aromatic hydrocarbons (PAHs) at PAH contaminated sites, Ambio 36 (2007) 475-485.

[6] K.C. Donnelly, H.J. Huebner, L.D. Claxton, J.A. Calvin, G.A. Vos, L. Cizmas, L.-Y. He, Biodegradation of simple chemical mixtures in soil, Environ. Toxicol. Chem. 24 (2005) 2839-2845.

[7] C.L. Lemieux, K.D. Lynes, P.A. White, S. Lundstedt, L. Öberg, I.B. Lambert, Mutagenicity of an aged gasworks soil during bioslurry treatment, Environ. Mol. Mutagen. 50 (2009) 404-412.

[8] B.A.M. Bandowe, N. Shukurov, M. Kersten, W. Wilcke, Polycyclic aromatic hydrocarbons (PAHs) and their oxygen-containing derivatives (OPAHs) in soils from the Angren industrial area Uzbekistan, Environ. Pollut. 158 (2010)2888-2899.

[9] H.P.H. Arp, S. Lundstedt, S. Josefsson, G. Cornelissen, A. Enell, A.-S. Allard, D.B. Kleja, Native OxyPAHs, N-PACs, and PAHs in historically contaminated soils from Sweden, Belgium, and France: their soil-porewater partitioning behavior, bioaccumulation in Enchytraeus crypticus, and bioavailability, Environ. Sci. Technol. 48 (2014) 11187-11195.

[10] S. Meyer, S. Cartellieri, H. Steinhart, Simultaneous determination of PAHs, hetero-PAHs (N, S, O), and their degradation products in creosote-contaminated soils. Method development, validation, and application to hazardous waste sites, Anal. Chem. 71 (1999) 4023-4029.

[11] C. Biache, L. Mansuy-Huault, P. Faure, C. Munier-Lamy, C. Leyval, Effects of thermal desorption on the composition of two coking plant soils: impact on solvent extractable organic compounds and metal bioavailability, Environ. Pollut. 156 (2008) 671-677.

[12] T. Ghislain, P. Faure, R. Michels, Detection and monitoring of PAH and oxy-PAHs by high-resolution mass spectrometry: comparison of ESI, APCI and APPI source detection, J. Am. Soc. Mass Spectrom. 23 (2012) 530-536.

[13] S. Lundstedt, B.A.M. Bandowe, W. Wilcke, E. Boll, J.H. Christensen, J. Vila, M. Grifoll, P. Faure, C. Biache, C. Lorgeoux, M. Larsson, K. Frech Irgum, P. Ivarsson, M. Ricci, First intercomparison study on the analysis of oxygenated polycyclic aromatic hydrocarbons (oxy-PAHs) and nitrogen heterocyclic polycyclic aromatic compounds (N-PACs) in contaminated soil, TrAC Trend. Anal. Chem.57 (2014) 83-92. 
[14] S. Lundstedt, P. Haglund, L. Öberg, Degradation and formation of polycyclic aromatic compounds during bioslurry treatment of an aged gasworks soil, Environ. Toxicol. Chem. 22 (2003) 1413-1420.

[15] C.E. Cerniglia, Biodegradation of polycyclic aromatic hydrocarbons, Biodegradation 3 (1992) 351368.

[16] C.E. Cerniglia, Fungal metabolism of polycyclic aromatic hydrocarbons: past, present and future applications in bioremediation, J. Ind. Microbiol. Biotechnol. 19 (1997) 324-333.

[17] B.E. Andersson, T. Henrysson, Accumulation and degradation of dead-end metabolites during treatment of soil contaminated with polycyclic aromatic hydrocarbons with five strains of whiterot fungi, Appl. Microbiol. Biotechnol.46 (1996) 647-652.

[18] M. Eriksson, G. Dalhammar, A.K. Borg-Karlson, Biological degradation of selected hydrocarbons in an old PAH/creosote contaminated soil from a gaswork site, Appl. Microbiol. Biotechnol. 53 (2000) $619-626$.

[19] B.E. Andersson, S. Lundstedt, K. Tornberg, Y. Schnürer, L.G. Öberg, B. Mattiasson, Incomplete degradation of polycyclic aromatic hydrocarbons in soil inoculated with wood-rotting fungi and their effect on the indigenous soil bacteria, Environ. Toxicol. Chem. 22 (2003) 1238-1243.

[20] H. Cui, C. Wang, Z. Gu, H. Zhu, S. Fu, Q. Yao, Evaluation of soil storage methods for soil microbial community using genetic and metabolic fingerprintings, Eur. J. Soil Biol. 63 (2014) 55-63.

[21] M. Pesaro, F. Widmer, G. Nicollier, J. Zeyer, Effects of freeze-thaw stress during soil storage on microbial communities and methidathion degradation, Soil Biol. Biochem. 35 (2003) 1049-1061.

[22] M. Shishido, C.P. Chanway, Storage effects on indigenous soil microbial communities and PGPR efficacy, Soil Biol. Biochem. 30 (1998) 939-947.

[23] C. Achten, S. Cheng, K.L. Straub, T. Hofmann, The lack of microbial degradation of polycyclic aromatic hydrocarbons from coal-rich soils, Environ. Pollut. 159 (2011) 623-629.

[24] Y. Li, R. Michels, L. Mansuy, S. Fleck, P. Faure, Comparison of pressurized liquid extraction with classical solvent extraction and microwave-assisted extraction-application to the investigation of the artificial maturation of Mahakam coal, Fuel 81 (2002) 747-755.

[25] C. Biache, C. Lorgeoux, S. Andriatsihoarana, S. Colombano, P. Faure, Effect of pre-heating on the chemical oxidation efficiency: implications for the PAH availability measurement in contaminated soils, J. Hazard. Mater. 286 (2015) 55-63. 
[26] A. Felske, A.D.L. Akkermans, W.M. De Vos, Quantification of $16 \mathrm{~S}$ rRNAs in complex bacterial communities by multiple competitive reverse transcription-PCR in temperature gradient gel electrophoresis fingerprints, Appl. Environ. Microbiol. 64 (1998) 4581-4587.

[27] E. Smit, P. Leeflang, B. Glandorf, J. Dirk van Elsas, K. Wernars, Analysis of fungal diversity in the wheat rhizosphere by sequencing of cloned PCR-amplified genes encoding 18S rRNA and temperature gradient gel electrophoresis, Appl. Environ. Microbiol. 65 (1999) 2614-2621.

[28] E.J. Vainio, J. Hantula, Direct analysis of wood-inhabiting fungi using denaturing gradient gel electrophoresis of amplified ribosomal DNA, Mycol. Res. 104 (2000) 927-936.

[29] A. Cébron, M.-P. Norini, T. Beguiristain, C. Leyval, Real-Time PCR quantification of PAH-ring hydroxylating dioxygenase (PAH-RHD $\alpha$ ) genes from Gram positive and Gram negative bacteria in soil and sediment samples, J. Microbiol. Meth. 73 (2008) 148-159.

[30] A.-I. Koukkou, E. Vandera, Hydrocarbon-degrading soil bacteria: current research, in: A.-I. Koukkou (Ed.), Microbial Bioremediation of Non-metals: Current Research, Caister Academic Press, Norfolk, UK, 2011, pp. 93-117.

[31] A. Cébron, P. Faure, C. Lorgeoux, S. Ouvrard, C. Leyval, Experimental increase in availability of a PAH complex organic contamination from an aged contaminated soil: consequences on biodegradation, Environ. Pollut. 177(2013) 98-105.

[32] A. Pernot, S. Ouvrard, P. Leglize, P. Faure, Protective role of fine silts for PAH in a former industrial soil, Environ. Pollut. 179 (2013) 81-87.

[33] A. Pernot, S. Ouvrard, P. Leglize, F. Watteau, D. Derrien, C. Lorgeoux, L. Mansuy-Huault, P. Faure, Impact of fresh organic matter incorporation on PAH fate in a contaminated industrial soil, Sci. Total Environ. 497-498 (2014) 345-352.

[34] M. Usman, A. Chaudhary, C. Biache, P. Faure, K. Hanna, Effect of thermal pre-treatment on the availability of PAHs for successive chemical oxidation in contaminated soils, Environ. Sci. Pollut. Res. 23 (2016) 1371-1380.

[35] X. Cui, W. Hunter, Y. Yang, Y. Chen, J. Gan, Biodegradation of pyrene in sand, silt and clay fractions of sediment, Biodegradation 22 (2011) 297-307.

[36] C. Biache, P. Faure, L. Mansuy-Huault, A. Cébron, T. Beguiristain, C. Leyval, Biodegradation of the organic matter in a coking plant soil and its main constituents, Org. Geochem. 56 (2013) 10-18. 
[37] S. Ouvrard, C. Barnier, P. Bauda, T. Beguiristain, C. Biache, M. Bonnard, C. Caupert, A. Cébron, J. Cortet, S. Cotelle, M. Dazy, P. Faure, J.F. Masfaraud, J. Nahmani, F. Palais, P. Poupin, N. Raoult, P. Vasseur, J.L. Morel, C. Leyval, In situ assessment of phytotechnologies for multicontaminated soil management, Int. J. Phytoremediat. 13 (2011) 245-263.

[38] Y. Liao, A. Geng, H. Huang, The influence of biodegradation on resins and asphaltenes in the Liaohe Basin, Org. Geochem. 40 (2009) 312-320.

[39] K.E. Peters, C.C. Walters, J.M. Moldowan, The Biomarker Guide, University Press, Cambridge, 2004.

[40] E.J. Joner, S.C. Corgié, N. Amellal, C. Leyval, Nutritional constraints to degradation of polycyclic aromatic hydrocarbons in a simulated rhizosphere, Soil Biol. Biochem. 34 (2002) 859-864.

[41] Y. Teng, Y. Luo, L. Ping, D. Zou, Z. Li, P. Christie, Effects of soil amendment with different carbon sources and other factors on the bioremediation of an aged PAH-contaminated soil, Biodegradation 21 (2010) 167-178.

[42] A.R. Johnsen, L.Y. Wick, H. Harms, Principles of microbial PAH-degradation in soil, Environ. Pollut. 133 (2005) 71-84.

[43] M.D. Aitken, W.T. Stringfellow, R.D. Nagel, C. Kazunga, S.-H. Chen, Characteristics of phenanthrene-degrading bacteria isolated from soils contaminated with polycyclic aromatic hydrocarbons, Can. J. Microbiol. 44 (1998) 743-752.

[44] C.D. Knightes, C.A. Peters, Aqueous phase biodegradation kinetics of 10 PAH compounds, Environ. Eng. Sci. 20 (2003) 207-218.

[45] K.H. Wammer, C.A. Peters, Polycyclic aromatic hydrocarbon biodegradation rates: a structurebased study, Environ. Sci. Technol. 39 (2005) 2571-2578.

[46] C. García-Delgado, I. Alfaro-Barta, E. Eymar, Combination of biochar amendment and mycoremediation for polycyclic aromatic hydrocarbons immobilization and biodegradation in creosote-contaminated soil, J. Hazard.Mater. 285 (2015) 259-266.

[47] X. Gong, X. Xu, Z. Gong, X. Li, C. Jia, M. Guo, H. Li, Remediation of PAH-contaminated soil at a gas manufacturing plant by a combined two-phase partition system washing and microbial degradation process, Environ. Sci. Pollut. Res. 22 (2015) 12001-12010.

[48] X. Li, P. Li, X. Lin, C. Zhang, Q. Li, Z. Gong, Biodegradation of aged polycyclic aromatic hydrocarbons (PAHs) by microbial consortia in soil and slurry phases, J. Hazard. Mater. 150 (2008) 21-26. 
[49] J. Sabaté, M. Viñas, A.M. Solanas, Bioavailability assessment and environmental fate of polycyclic aromatic hydrocarbons in biostimulated creosote-contaminated soil, Chemosphere 63 (2006) 1648-1659.

[50] C. Achten, J.T. Andersson, Overview of polycyclic aromatic compounds (PAC), Polycycl. Aromat. Comp. 35 (2015) 177-186.

[51] D. Ghosal, A. Dutta, J. Chakraborty, S. Basu, T.K. Dutta, Characterization of the metabolic pathway involved in assimilation of acenaphthene in Acinetobacter sp. strain AGAT-W, Res. Microbiol. 164 (2013) 155-163.

[52] M. Baboshin, V. Akimov, B. Baskunov, T. Born, S. Khan, L. Golovleva, Conversion of polycyclic aromatic hydrocarbons by Sphingomonas sp. VKMB-2434, Biodegradation 19 (2008) 567-576.

[53] T. Komatsu, T. Omori, T. Kodama, Microbial degradation of the polycyclic aromatic hydrocarbons acenaphthene and acenaphthylene by a pure bacterial culture, Biosci. Biotechnol. Biochem. 57 (1993) 864-865.

[54] S. Poonthrigpun, K. Pattaragulwanit, S. Paengthai, T. Kriangkripipat, K. Juntongjin, S. Thaniyavarn, A. Petsom, P. Pinphanichakarn, Novel intermediates of acenaphthylene degradation by Rhizobium sp. strain CU-A1: evidence for naphthalene-1,8-dicarboxylic acid metabolism, Appl. Environ. Microbiol. 72 (2006) 6034-6039.

[55] W.T. Stringfellow, M.D. Aitken, Competitive metabolism of naphthalene, methylnaphthalenes, and fluorene by phenanthrene-degrading pseudomonads, Appl. Environ. Microbiol. 61 (1995) 357-362.

[56] M.D. Jones, E.A. Rodgers-Vieira, J. Hu, M.D. Aitken, Association of growth substrates and bacterial genera with benzo[a]pyrene mineralization in contaminated soil, Environ. Eng. Sci. 31 (2014) 689697.

[57] T. Cajthaml, P. Erbanová, V. `Sa`sek, M. Moeder, Breakdown products on metabolic pathway of degradation of benz[a]anthracene by a ligninolytic fungus, Chemosphere 64 (2006) 560-564.

[58] J. Moody, J. Freeman, C. Cerniglia, Degradation of benz[a]anthracene by Mycobacterium vanbaalenii strain PYR-1, Biodegradation 16 (2005) 513-526.

[59] L.M. Carmichael, F.K. Pfaender, Polynuclear aromatic hydrocarbon metabolism in soils: relationship to soil characteristics and preexposure, Environ. Toxicol. Chem. 16 (1997) 666-675. 
[60] A.R. Johnsen, U. Karlson, PAH degradation capacity of soil microbial communities-does it depend on PAH exposure? Microb. Ecol. 50 (2005)488-495.

[61] R. Simarro, N. González, L.F. Bautista, M.C. Molina, Biodegradation of high-molecular-weight polycyclic aromatic hydrocarbons by a wood-degrading consortium at low temperatures, FEMS Microbiol. Ecol. 83(2013) 438-449.

[62] R.A. Kanaly, S. Harayama, Biodegradation of high-molecular-weight polycyclic aromatic hydrocarbons by bacteria, J. Bacteriol. 182 (2000) 2059-2067.

[63] A. Cébron, T. Beguiristain, P. Faure, M.-P. Norini, J.-F. Masfaraud, C. Leyval, Influence of vegetation on the in situ bacterial community and polycyclic aromatic hydrocarbon (PAH) degraders in aged PAH-contaminated or thermal-desorption-treated soil, Appl. Environ. Microbiol. 75 (2009)63226330. 


\section{BIOREMEDIATION OF PAH-CONTAMINED SOIL: CONSEQUENCES ON FORMATION AND DEGRADATION OF POLAR POLYCYCLIC AROMATIC COMPOUNDS AND MICROBIAL COMMUNITY ABUNDANCE}

Coralie Biache, Salma Ouali, Aurélie Cébron, Catherine Lorgeoux, Stéfan Colombano, Pierre Faure

\section{Supplementary Data}

\section{Microbial inoculum preparation}

The microbial inocula were prepared from the "fresh" soils. Glass beads ( $150 \mathrm{~g}, 1 \mathrm{~mm} \mathrm{~d}$.), $\mathrm{NaCl}$ solution ( $250 \mathrm{~mL}, 0.85 \%)$ and soil $(50 \mathrm{~g})$ were placed in $500 \mathrm{~mL}$-flasks and shaken on a rotary shaker (100 rpm, $1 \mathrm{~h})$. The mixtures were left to decant for $30 \mathrm{~min}$ before being filtrated successively on 150 and $5 \mu \mathrm{m}$ pore membranes. The final filtrates were centrifuged (4,500 rpm, $15 \mathrm{~min})$. Pellets were re-suspended with Bushnell Haas (BH) mineral broth solution (35 mL, $3.27 \mathrm{~g} / \mathrm{L}$; Sigma-Aldrich) to constitute the microbial inoculum.

\section{GC-MS analyses for PAC quantification}

The gas chromatograph (GC) was a Shimadzu GC-2010 plus, equipped with a capillary column in silica glass DB-5MS (60 m $\times 0.25 \mathrm{~mm}$ i.d. $\times 0.1 \mu \mathrm{m}$ film thickness) coupled to a QP2010-Ultra (Shimadzu) electronic ionization mass spectrometer (MS) operating at $70 \mathrm{eV}$ in alternate fullscan/selected ion monitoring mode with a transfer line heated at $300^{\circ} \mathrm{C}$. The oven temperature program was as follow: $70^{\circ} \mathrm{C}$ for $2 \mathrm{~min}$, from 70 to $130^{\circ} \mathrm{C}$ at $15^{\circ} \mathrm{C} / \mathrm{min}$, then from 130 to $315^{\circ} \mathrm{C}$ at $3^{\circ} \mathrm{C} / \mathrm{min}$ and then a $15 \mathrm{~min}$ hold at $315^{\circ} \mathrm{C}$. The carrier gas was helium at $1.4 \mathrm{~mL} / \mathrm{min}$ constant flow. Injections were done with 1 $\mu L$ in split mode with a split ratio of 1:5. 
Amplification reactions were carried out in $20 \mu \mathrm{L}$ containing iQ SYBR green Supermix (Bio-Rad, 10 $\mu \mathrm{L}$ ), $0.8 \mu \mathrm{L}$ of each primer $(10 \mathrm{mM})$, bovine serum albumin $(3 \%, 0.4 \mu \mathrm{L})$, dimethyl sulfoxide $(0.2 \mu \mathrm{L}), \mathrm{T} 4$ bacteriophage gene 32 product (MP Biomedicals, $0.08 \mu \mathrm{L}$ ), and $1 \mu \mathrm{L}$ of template DNA (genomic DNA or 10 -time dilution series of standard plasmids, from $10^{8}$ to $10^{1}$ gene copies. $\mu \mathrm{L}^{-1}$ ) or $1 \mu \mathrm{L}$ of distilled water (negative control). The amplifications were carried out with the following temperature profiles: heating to $95{ }^{\circ} \mathrm{C}(5 \mathrm{~min})$, followed by 40 cycles of four steps: $20 \mathrm{~s}$ at $95{ }^{\circ} \mathrm{C}, 20 \mathrm{~s}$ at the primer-specific annealing temperatures $\left(56^{\circ} \mathrm{C}\right.$ for $16 \mathrm{~S}$ rRNA, $50^{\circ} \mathrm{C}$ for $18 \mathrm{~S}$ rRNA, $57^{\circ} \mathrm{C}$ for PAH-RHD $\alpha$ GN and $54^{\circ} \mathrm{C}$ for PAH-RHD $\alpha \mathrm{GP}$ ), $30 \mathrm{~s}$ at $72{ }^{\circ} \mathrm{C}$, and $5 \mathrm{~s}$ at $82{ }^{\circ} \mathrm{C}$ to dissociate the primer's dimers and capture the fluorescence intensity of the SYBR green. At the end, a melting curve analysis was performed from 50 ${ }^{\circ} \mathrm{C}$ to $95^{\circ} \mathrm{C}$ with a temperature increase of $0.5^{\circ} \mathrm{C} / 5 \mathrm{~s}$. 
Table S1 :Total $\mathrm{N}$, organic matter, $\mathrm{pH}$, total $\mathrm{CaCO}_{3}$ and available $\mathrm{P}_{2} \mathrm{O}_{5}$ determined for the initial soils according to the NF ISO 13878, NF ISO 10694, NF ISO 10390, NF ISO 10693 and NF ISO 11263 French standards, respectively [1], percentage of modern carbon (pMC), determined by radiocarbon analysis [2], and specific area previously reported [3]

\begin{tabular}{lrrr}
\hline & Gas plant & Coking plant & Wood-treating facility \\
\hline total N $(\mathrm{g} / \mathrm{kg})$ & 1.32 & 2.34 & 3.46 \\
$\mathrm{C} / \mathrm{N}$ & 29.9 & 24.9 & 48.9 \\
Organic matter $(\mathrm{g} / \mathrm{kg})$ & 68.4 & 101 & 292 \\
$\mathrm{pH}$ & 7.67 & 7.49 & 7.83 \\
total $\mathrm{CaCO}_{3}(\mathrm{~g} / \mathrm{kg})$ & 5 & 17 & 106 \\
available $\mathrm{P}_{2} \mathrm{O}_{5}(\mathrm{~g} / \mathrm{kg})$ & 0.092 & 0.059 & 0.007 \\
pMC $^{1}(\%)$ & 14.7 & 5.6 & 21.8 \\
specific area $\left(\mathrm{m}^{2} / \mathrm{g}\right)$ & $4.6 \pm 0.3$ & $9.8 \pm 0.2$ & $2.1 \pm 0.4$ \\
\hline
\end{tabular}

${ }^{1} \mathrm{pMC}$ : percentage of modern carbon

[1] AFNOR, Evaluation de la qualité des sols, France, 2004.

[2] L. Jeanneau, P. Faure, Quantification of fossil organic matter in contaminated sediments from an industrial watershed: Validation of the quantitative multimolecular approach by radiocarbon analysis, Sci. Total Environ., 408 (2010) 4251-4256.

[3] C. Biache, C. Lorgeoux, S. Andriatsihoarana, S. Colombano, P. Faure, Effect of pre-heating on the chemical oxidation efficiency: Implications for the PAH availability measurement in contaminated soils, J. Hazard. Mater., 286 (2015) 55-63. 
Table S2: List of the quantified polycyclic aromatic compounds (PAC) with their number of rings and their molecular weights.

\begin{tabular}{|c|c|c|}
\hline PAHs & Number of ring & Molecular weight $(\mathrm{g} / \mathrm{mol})$ \\
\hline Naphthalene & 2 & 128 \\
\hline Acenaphthylene & 3 & 152 \\
\hline Acenaphthene & 3 & 154 \\
\hline Fluorene & 3 & 166 \\
\hline Phenanthrene & 3 & 178 \\
\hline Anthracene & 3 & 178 \\
\hline Fluoranthene & 4 & 202 \\
\hline Pyrene & 4 & 202 \\
\hline Benz $[a]$ anthracene & 4 & 228 \\
\hline Chrysene & 4 & 228 \\
\hline Benzo[b]fluoranthene & 5 & 252 \\
\hline Benzo[k]fluoranthene & 5 & 252 \\
\hline Benz $[a]$ pyrene & 5 & 252 \\
\hline Perylene & 5 & 252 \\
\hline Indeno[1,2,3-cd]pyrene & 6 & 276 \\
\hline Dibenz $[a, h]$ anthracene & 5 & 278 \\
\hline Benzo[ghi]perylene & 6 & 276 \\
\hline \multicolumn{3}{|l|}{ O-PACS } \\
\hline Dibenzofuran & 3 & 168 \\
\hline 9H-fluorenone & 3 & 180 \\
\hline Perinaphthenone & 3 & 180 \\
\hline 9,10-Anthraquinone & 3 & 208 \\
\hline Cyclopenta[def]phenanthrone & 4 & 204 \\
\hline 2-Methylanthracene-9,10-dione & 3 & 222 \\
\hline Benz $[a]$ fluorenone & 4 & 230 \\
\hline 1,9-Benz-10-anthrone & 4 & 230 \\
\hline Benz $[a]$ anthracene-7,12-dione & 4 & 258 \\
\hline Naphthacene-5,12-dione & 4 & 258 \\
\hline Benzo[cd]pyrenone & 5 & 254 \\
\hline \multicolumn{3}{|l|}{ N-PACS } \\
\hline Quinoline & 2 & 129 \\
\hline Benzo[h]quinoline & 3 & 179 \\
\hline Acridine & 3 & 179 \\
\hline Carbazole & 3 & 167 \\
\hline Nitropyrene & 4 & 247 \\
\hline
\end{tabular}




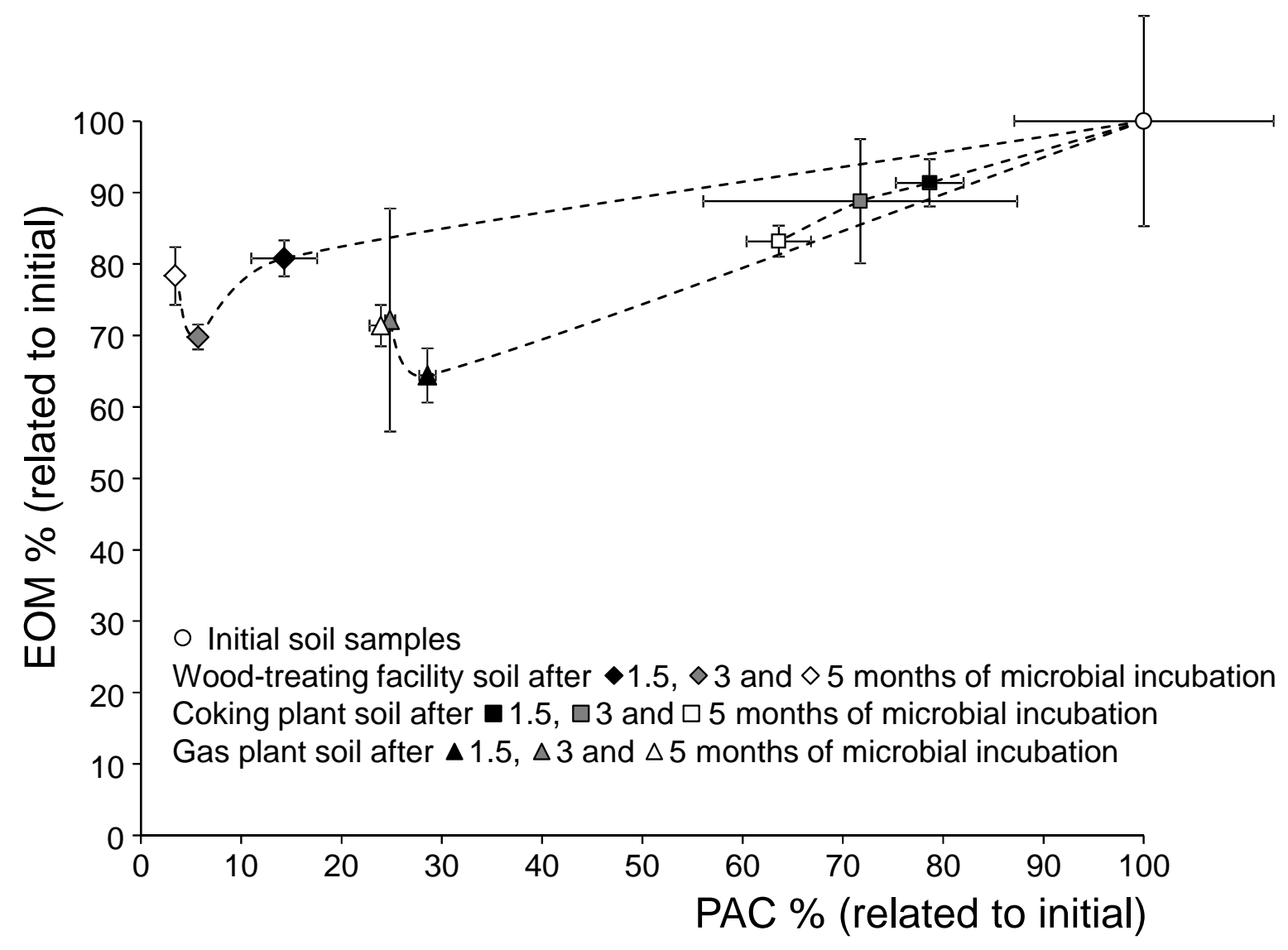

Figure S1: Extractable organic matter (EOM) and polycyclic aromatic compound (PAC) proportions in the soils, after $1.5,3$ and 5 months of microbial incubation $(n=3 ; \pm S D)$ 